\title{
Replication of Flaviviruses
}

\author{
Margo A. Brinton
}

\section{INTRODUCTION}

Flaviviruses were classified as members of the togavirus family until 1984, when the International Committee for the Nomenclature of Viruses voted to make Flaviviridae a separate family (Westaway et al., 1986). The togavirus family had originally been defined using morphological criteria. The change in classification was the result of recent research that clearly demonstrated that flaviviruses, although generally similar to alphaviruses in their morphology, differ markedly from the alpha togaviruses in their virion structure, strategy of replication, and morphogenesis.

There are currently 64 identified flaviviruses, of which yellow fever (YF) virus is the prototype. The family name is derived from the Latin word flavus, which means "yellow." All flaviviruses share a group-specific antigen and the flaviviruses have been subdivided into subgroups and complexes on the basis of their serological cross-reactivity and the type of arthropod vector by which each virus is transmitted during its natural cycle (Table I) (Chamberlain, 1980; Calisher et al., 1986). Virus abbreviations used in the text are given in Table I.

A number of the flaviviruses are human pathogens that regularly cause significant human morbidity and mortality throughout the world. Dengue virus infections in Asia and also, recently, in the Caribbean are of special public health concern because dengue virus infections can lead to an often fatal hemorrhagic fever termed dengue shock syndrome (Shope, 1980; Halstead, 1981). Japanese (JE), Murray Valley (MVE), St. Louis encephalitis (SLE), West Nile (WN), and Rocio encephalitis viruses are periodically responsible for epidemics or scattered cases of human central nervous system (CNS) disease and fever often distributed over

MARGO A. BRINTON • The Wistar Institute of Anatomy and Biology, Philadelphia, Pennsylvania 19104. 
TABLE I. Antigenic and Vector Classification of Flaviviruses

\begin{tabular}{|c|c|c|c|c|c|}
\hline Mosquito-borne & $\begin{array}{l}\text { Anti- } \\
\text { genic } \\
\text { group }^{a}\end{array}$ & Tick-borne & $\begin{array}{l}\text { Anti- } \\
\text { genic } \\
\text { group }^{a}\end{array}$ & Vector unknown & $\begin{array}{l}\text { Anti- } \\
\text { genic } \\
\text { group }^{a}\end{array}$ \\
\hline Alfuy & III & Kadam & I & Carey Island & I \\
\hline Bussuquara & III & Karshi & I & Negishi & I \\
\hline $\begin{array}{l}\text { Japanese } \\
\text { encephalitis }\end{array}$ & III & $\begin{array}{l}\text { Kyasanur Forest } \\
\text { disease }\end{array}$ & I & Phnom Penh bat & I \\
\hline (JE) & & Langat & I & Cowbone Ridge & II \\
\hline Kunjin & III & Louping ill & I & Jutiapa & II \\
\hline $\begin{array}{l}\text { Murray Valley } \\
\text { encephalitis } \\
\text { (MVE) }\end{array}$ & III & $\begin{array}{l}\text { Omsk hemorrhagic } \\
\text { fever } \\
\text { Powassan }\end{array}$ & I & $\begin{array}{l}\text { Moc } \\
\text { Sal Vieja } \\
\text { Erlita }\end{array}$ & $\begin{array}{l}\text { II } \\
\text { II } \\
\text { II }\end{array}$ \\
\hline $\begin{array}{l}\text { Saint Louis } \\
\text { encephalitis }\end{array}$ & III & Royal Farm & I & Koutango & III \\
\hline $\begin{array}{l}\text { encephalitis } \\
\text { (SLE) }\end{array}$ & & $\begin{array}{l}\text { Saumarez Reef } \\
\text { Tick-borne }\end{array}$ & $\begin{array}{l}\text { I } \\
\text { I }\end{array}$ & Israel turkey & VII \\
\hline Stratford & III & encephalitis & & meningoencephalitis & \\
\hline Usutu & III & (TBE) & & Apoi & VII \\
\hline West Nile (WN) & III & $\begin{array}{l}\text { Russian spring- } \\
\text { summer }\end{array}$ & 1 & $\begin{array}{l}\text { Bukalasae bat } \\
\text { Dakar bat }\end{array}$ & $\begin{array}{l}\text { VII } \\
\text { VII }\end{array}$ \\
\hline Bagaza & IV & Tyuleniv & $\mathrm{U}$ & Entebbe bat & VII \\
\hline Kokobera & IV & Tyuleniy & & Rio Bravo & VII \\
\hline Ntaya & IV & & & Saboya & VII \\
\hline Tembusu & IV & & & Aroa & $\mathrm{U}$ \\
\hline Yokose & IV & & & Cacipacore & $\mathrm{U}$ \\
\hline Banzi & $\mathrm{V}$ & & & Gadgets Gully & $\mathrm{U}$ \\
\hline Bouboui & $\mathrm{V}$ & & & Montana myotis & $\mathrm{U}$ \\
\hline Edge hill & V & & & leukoencephalitis & \\
\hline Uganda S & V & & & Rocio & $\mathrm{U}$ \\
\hline Dengue-1 & VI & & & Sokuluk & $\mathrm{U}$ \\
\hline Dengue-2 & VI & & & & \\
\hline Dengue-3 & VI & & & & \\
\hline Dengue-4 & VI & & & & \\
\hline Ilheus & $\mathrm{U}$ & & & & \\
\hline Jugra & $\mathrm{U}$ & & & & \\
\hline Naranjal & $\mathrm{U}$ & & & & \\
\hline Sepik & $\mathrm{U}$ & & & & \\
\hline Sponweni & $\mathrm{U}$ & & & & \\
\hline Yellow fever (YF) & $\mathrm{U}$ & & & & \\
\hline Wesselsbron & U & & & & \\
\hline Zika & $\mathrm{U}$ & & & & \\
\hline
\end{tabular}

${ }^{a}$ Antigenic groups are designated I, II, III, IV, V, VI, VII, and U (unknown). 
extensive geographic areas. Infections with many of the other flaviviruses cause morbidity and mortality preferentially in the very young and the elderly, but humans of all ages can be afflicted (Shope, 1980). The tickborne flaviviruses, such as Powassan, louping ill, Kyasanur Forest disease, tick-borne encephalitis (TBE), Russian spring summer, and Omsk hemorrhagic fever viruses, induce human meningitis or encephalitis with a case fatality rate ranging from 1 to $30 \%$ (Shope, 1980). Disease can result from replication of flaviviruses in peripheral organs or in cells in the CNS (Harrison et al., 1982; Grimley, 1983). A recent study by Monath et al. (1983) indicates that during the course of a natural infection initiated by the bite of an arthropod vector, virus may gain access to the CNS, not by passive diffusion through brain capillaries, but by a neural olfactory pathway. Their results obtained with intraperitoneal SLE virus infections of Syrian hamsters indicated that a low-level viremia led to the infection of highly susceptible Bowman gland cells in the olfactory neuroepithelium. This was followed by centripetal axon transport of virus to the olfactory bulb and subsequent spread of virus throughout the CNS. Infection of cells in the nasal mucosa and the presence of virus in nasal mucus could result in non-arthropod-borne virus transmission.

For more extensive coverage of work published on flaviviruses prior to 1980 , the reader is referred to several previous reviews (R. W. Schlesinger, 1977; J. H. Strauss and Strauss, 1977; Monath, 1980; Westaway, 1980; Russell et al., 1980; Halstead, 1980|.

\section{VIRION MORPHOLOGY AND COMPOSITION}

\section{A. Morphology}

Flaviviruses contain a central nucleocapsid surrounded by a lipid bilayer. Virions are spherical and have a diameter of about $40-50 \mathrm{~nm}$. Their cores are 25-30 $\mathrm{nm}$ in diameter. Along the outer surface of the virion envelope are projections that are 5-10 nm long with terminal knobs 2 $\mathrm{nm}$ in diameter (Murphy, 1980).

\section{B. Physicochemical Properties and Chemical Composition}

The buoyant density of flavivirions is $1.22-1.24 \mathrm{~g} / \mathrm{cm}^{3}$ in $\mathrm{CsCl}$ and $1.18-1.20 \mathrm{~g} / \mathrm{cm}^{3}$ in sucrose. The sedimentation coefficient for virions in sucrose has been reported to be 175-218 S. The infectivity of virions is most stable in the range of $\mathrm{pH} 7-9$. Virions are rapidly inactivated at $50^{\circ} \mathrm{C}$, with infectivity decreasing by $50 \%$ in $10 \mathrm{~min}$ at this temperature (Porterfield et al., 1978). Virion infectivity is also sensitive to inactivation by ultraviolet light, ionic and nonionic detergents, and trypsin digestion. The chemical composition of a representative flavivirus, SLE virus, is 
TABLE II. Composition of Flaviviruses ${ }^{a}$

\begin{tabular}{lc}
\hline \multicolumn{1}{c}{ Component } & $\begin{array}{c}\text { Percentage of total } \\
\text { dry weight }\end{array}$ \\
\hline Protein & 66 \\
RNA & 6 \\
GC content $=48 \%$ & 12 \\
Carbohydrate & 3 \\
Neutral carbohydrate & 6 \\
Hexosamine & 3 \\
$N$-Acetyl neuraminic acid & 17 \\
Lipids & \\
Molar ratio of cholesterol to & 12 \\
phopholipid $=0.29$ & 5 \\
Phospholipid & \\
Neutral lipid & \\
\hline${ }^{a}$ Values given were obtained for SLE virus by Trent and Naeve \\
(1980).
\end{tabular}

shown in Table II. The majority of the carbohydrate in virions is present in glycoprotein, but a small amount of glycolipid is also present. Various types of tissue-culture cells that differ in their phospholipid composition have been found to produce progeny flavivirions with a phospholipid composition similar to that of the host cell (Trent and Naeve, 1980). For instance, Vero cells and SLE grown in these cells contain less sphingomyelin and phosphatidylserine than do baby hamster kidney (BHK) cells or virus grown in BHK cells (Trent and Naeve, 1980). These results indicate that the virion phospholipids are derived from preexisting hostcell lipids. No matter what cell type was used, however, the percentage of the total phospholipid represented by sphingomyelin and phosphatidylserine was always higher in the virions than in the host cells, whereas the percentage of phosphatidylcholine was similar in virions and host cells. The lipid composition of the virion appears to be determined by the intracellular membrane site of virus maturation. This aspect of viral morphogenesis is discussed in more detail in Section IV.

\section{Structural Proteins}

Flavivirions contain three types of polypeptides (Fig. 1). The glycosylated envelope $(E)$ protein $\left(M_{r} \approx 51-59 \times 10^{3}\right)$ is located in the virion envelope and forms the observed spike projections on the outer surface of the virions. It is currently not known whether these spikes represent monomers, dimers, or trimers of the $\mathrm{E}$ protein. The carbohydrate moieties of the $\mathrm{E}$ protein have been reported to be primarily mannose and complex glycans. The membrane $(M)$ protein $\left(M_{r} \approx 7-9 \times 10^{3}\right)$ is also associated with the virion envelope, but is not glycosylated. Both the $\mathrm{E}$ and $\mathrm{M}$ proteins are solubilized after treatment of virions with a nonionic detergent 
FIGURE 1. Virion proteins of SLE. Coelectrophoresis of $\left[{ }^{14} \mathrm{C}\right]$ amino-acid-labeled $(\bullet)$ and $\left[{ }^{3} \mathrm{H}\right]$ glucosamine-labeled (O) SLE structural proteins on a $13 \%$ sodium dodecyl sulfate-polyacrylamide gel. From Trent and Naeve (1980).

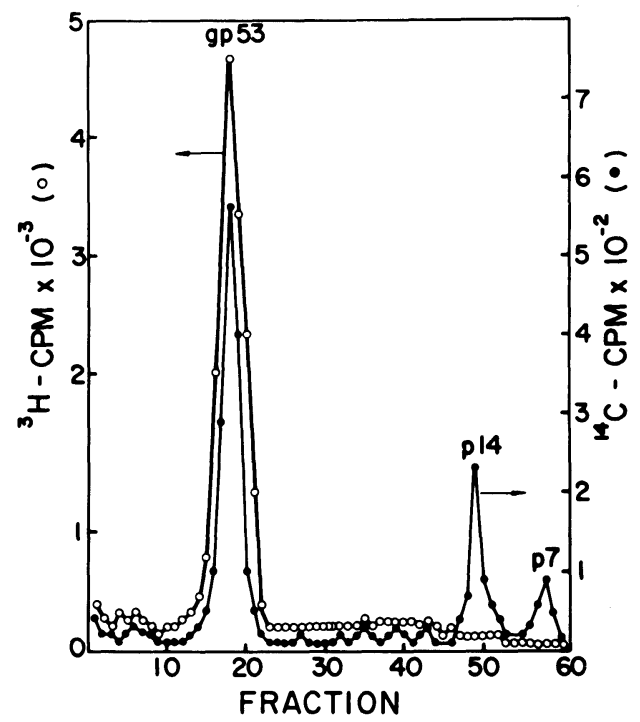

(Westaway and Reedman, 1969). The genome RNA is contained within a central core structure composed exclusively of the capsid (C) protein $\left(\mathrm{M}_{\mathrm{r}} \approx 13-16 \times 10^{3}\right)$. The symmetry of the nucleocapsid structure has not been determined rigorously, but is thought to be icosahedral.

Tryptic peptide maps of the three structural proteins of several of the flaviviruses indicate that each is a unique protein (Wright and Westaway, 1977). The isoelectric points of detergent-solubilized flavivirus $\mathrm{E}$ and $C$ proteins have been determined to be $7.6-7.8$ and $10.2-10.4$, respectively (Trent, 1977).

The primary immune response to flaviviruses during infection is directed toward the surface epitopes of the E protein. The hemagglutinating activity of flavivirions resides in the E protein. E protein from JE virions that had been purified by means of sodium dodecyl sulfate (SDS)-polyacrylamide gels and subsequently renatured by ion-exchange chromatography was found to agglutinate red blood cells and to bind to hemagglutination-inhibiting antibodies in anti-JE virus sera. The purified E protein was also shown to be able to elicit neutralizing antibody when injected into mice (Takegami et al., 1982). Purified C protein elicited no neutralizing antibody, whereas neutralizing activity was elicited by purified $M$ protein. The $C$ protein has been found to have group-reactive antigenic determinants. The role of the $\mathrm{M}$ protein in flavivirus replication and in the assembly of virions is currently unknown. Lee and Schloemer (1981) reported that if uninfected host cells were pretreated with purified Banzi virus $M$ protein, interference was observed with a subsequent Banzi virus infection. These data suggest that a part of the $M$ protein may be exposed on the surface of flavivirions and that the $M$ protein may interact with the cell surface. The E protein also presumably contains a site that interacts with the cell surface during virion attachment. 
The 64 different viruses that constitute the flavivirus family demonstrate a variety of complex antigenic interrelationships with each other. Recently, panels of monoclonal antibodies have been generated against several flaviviruses, such as TBE virus (Stephenson et al., 1984; Heinz et al., 1983), YF virus (J. J. Schlesinger et al., 1983), WN virus (Peiris et al., 1982), SLE virus (Roehrig et al., 1983), and the four serotypes of dengue virus (Henchal et al., 1982). With the use of these monoclonal antibodies, attempts have been made to identify the epitopes on the viral E glycoprotein that are involved in virus neutralization, hemagglutination, immune enhancement, and type-, subcomplex-, super-complex-, and group-specific antigenic cross-reactivity. Heinz et al. (1983), using a panel of TBE virus monoclones, J. J. Schlesinger et al. (1983), using a panel of YF virus monoclones, and Roehrig et al. (1983), using a panel of SLEmonoclones, each defined at least eight distinct epitopes on the E glycoprotein (see Chapter 9).

Flavivirions have sometimes been found to contain a nonstructural glycoprotein incorporated into virion envelopes in addition to or in lieu of the M protein (Shapiro et al., 1972a-c; Westaway and Shew, 1977; Wright, 1982). Such virions have been observed extracellularly when virus is produced in the presence of Tris-buffered medium and intracellularly when virus is grown with normal tissue-culture media. Recent nucleotide sequence data obtained with YF virus indicate that the $M$ protein is indeed cleaved from a glycosylated precursor protein $\left(M_{\mathrm{r}} \approx 19-23 \times 10^{3}\right)$ (Rice et al., 1985) (see Chapter 10).

Differences in the extent of glycosylation of the flavivirion E protein have been reported. G. W. Smith and Wright (1985) found that the E protein from dengue 2 virions grown in Vero cells migrated more slowly in SDS-containing polyacrylamide gels than did the E protein from dengue 2 virions grown in C6/36 mosquito cells. The contribution of carbohydrate to the molecular weight of the E glycoprotein is approximately 4000 daltons. An increased electrophoretic mobility of the envelope glycoproteins of two alphaviruses, Sindbis virus and Semliki Forest virus, grown in mosquito cells was previously shown to result from the absence of sialic acid residues (Stollar et al., 1976; Luukkonen et al., 1977). Virusspecified glycoproteins of virus grown in cultured mosquito cells presumably lack sialic acid because mosquito cells do not possess a sialyl transferase (Stollar et al., 1976). However, in the case of flaviviruses, the absence of sialic acid could not account entirely for the E-protein migration differences observed. Comparison of glycopeptides indicated that the E proteins are modified at a late stage of their maturation by proteolysis or glycan processing or both (G. W. Smith and Wright, 1985). Kunjin virus grown in Vero cells has been found to contain E protein that is not glycosylated (Wright, 1982). The E protein of extracellular Kunjin virions could not be labeled with radioactive galactose, mannose, or glucosamine, had a density in $\mathrm{CsCl}$ consistent with that of a protein lacking carbohydrate, and did not bind to concanavalin A-agarose. Interestingly, two 


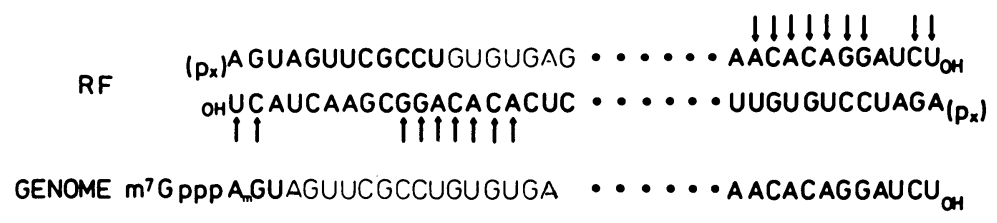

FIGURE 2. Terminal sequences of WN-virus-specific RNAs. Identical sequences are present in the $3^{\prime}$-terminal regions of both the genome and replicative form (RF) RNA as indicated by arrows. The nature of the $5^{\prime}$-terminal structures of the RF is not known, but may consist of one or more phosphates. From Wengler and Wengler (1981).

precursors of E, gp66 and gp59, and the intracellular form of the E protein in Kunjin-infected cells have been shown to be glycosylated (Wright and Warr, 1985). The E proteins obtained from extracellular virions produced during all other flavivirus infections studied so far definitely do contain oligosaccharides. However, at least two forms of the E protein with different molecular weights have been found in YF strain 17D virions (J. J. Schlesinger et al., 1983) and TBE virions (Heinz and Kunz, 1982). SLEvirus-specified intracellular $\mathrm{E}$ protein was separable into several fractions by DEAE-cellulose chromatography. The E proteins present in these fractions differed markedly in the ratio of glucosamine to leucine (Qureshi and Trent, 1973a-c).

\section{Genome RNA}

Flavivirions contain a single-stranded RNA (ssRNA) with a molecular weight of about $4 \times 10^{6}$ and a sedimentation coefficient in sucrose gradients of 40-44 S. Examination of YF virus RNA under the electron microscope in the presence of $4 \mathrm{M}$ urea and $80 \%$ formamide revealed a linear molecule of about 11,000 bases (Deubel et al., 1983). The purified genome RNA is infectious and is designated as "plus"-stranded. The RNA contains a type $15^{\prime}$-terminal $\mathrm{M}^{7} \mathrm{GpppAmp} \mathrm{N}_{1}$ cap structure (Cleaves and Dubin, 1979; Wengler et al., 1978).

The $3^{\prime}$ terminus of the flavivirus genome is not polyadenylated. Instead, the genome has been shown to terminate in $\mathrm{CU}_{\mathrm{OH}}$ (Wengler and Wengler, 1981; Rice et al., 1985; Brinton et al., 1986). The same heptanucleotide, $\left(3^{\prime}\right)$ GGACACA $\left(5^{\prime}\right)$, was found to be present near the $3^{\prime}$ termini of both the plus-and minus-strand RNAs of WN and YF and near the $3^{\prime}$ termini of JE and SLE genomic RNAs (Fig. 2) (Wengler and Wengler, 1981; Rice et al., 1985; Dalrymple and Trent, personal communications). Although the first two $3^{\prime}$-terminal nucleotides and the heptanucleotide sequence appear to be highly conserved, the intervening nucleotides appear not to be conserved. Even two strains of WN virus were found to differ by one nucleotide in this region (Wengler and Wengler, 1981; Brinton et al., 1986)(see Figs. 2 and 3). It has been suggested that the conserved 


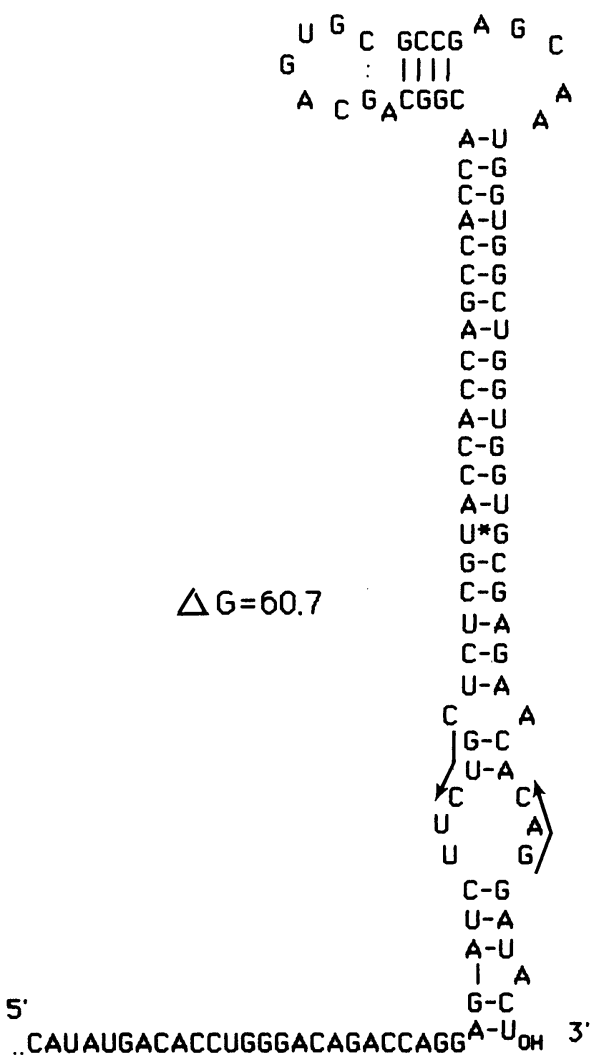

FIGURE 3. 3'-Terminal sequence of WN virus, strain E101. The first 84 nucleotides form a stable stem and loop structure. From Brinton et al. (1986).

sequences may be important for polymerase recognition or binding or both.

The entire genome RNA of the 17D strain of YF virus has recently been sequenced from complementary DNA (cDNA) (Rice et al., 1985), and direct RNA sequence data have been obtained for the $3^{\prime}$ end of the WN virus, strain E101, genome (Brinton et al., 1986). A fairly stable, complex stem and loop structure (Fig. 3) appears to be located at the $3^{\prime}$ end of the genome RNA (Brinton et al., 1986). The existence of this structure was demonstrated by RNase digestion patterns of $3^{\prime}$-labeled WN virion RNA. Nucleotides within the stem structure were inefficiently digested, while nucleotides within the loops located at the top of the stem were cut efficiently (Brinton et al., 1986). A DNA primer complementary to the 5 th through the 21 st 3 ' nucleotides of WN virion RNA was unable to initiate reading within the hairpin stem, even when primer and template were heated together and then slow cooled and/or the dideoxy sequencing reactions were incubated at $50^{\circ} \mathrm{C}$. Although a consistent sequence was obtained with this primer, this sequence was not found in the first 150 nucleotides from the $3^{\prime}$ termini of the RNA. This result indicates that this primer binds to a second site farther downstream in the RNA (Brinton et al., 1986). A 3'-terminal stem and loop structure 
has also been predicted from the cDNA sequence generated by Rice $e t$ al. (1985) (see Chapter 10). Although the 3'-terminal stem and loop structures of WN virus, strain E101, and YF virus, strain 17D, differ significantly in sequence, they are very similar in length and form. A second heptanucleotide sequence located on the descending arm of the stem and aligning, but not base-pairing, with the conserved heptanucleotide sequence identified by Wengler and Wengler (1981) also appears to be highly conserved. The 3' stem and loop structure may be important in regulating the initiation of minus-strand RNA synthesis, which is less efficient than plus-strand synthesis. This structure could also be involved in genome RNA interactions with capsid proteins. Further information about the structure and arrangement of the genes can be found in the flavivirus genome in Chapter 10.

The arrangement of genes within the flavivirus RNA is quite different from the gene arrangement of the alpha togaviruses and more closely resembles that of the picornaviruses; the virion structural proteins are encoded at the $5^{\prime}$ end of the genome. The first gene encoded at the $5^{\prime}$ end of the flavivirus genome is the C-protein gene, followed by the M-protein gene and then the E-protein gene (5'-C-M-E-3') (Rice et al., 1985).

\section{INFECTION OF CULTURED CELLS}

Flaviviruses can replicate in a wide variety of cultured cells of vertebrate and arthropod origin. In mammalian and avian cells, flaviviruses replicate at a significantly slower rate than the alphaviruses. The initial latent phase of the flavivirus replication cycle lasts about $12 \mathrm{hr}$, after which progeny virus begins to be released from infected cells. Maximal titers of virus do not begin to be produced until $24 \mathrm{hr}$ after infection (Trent and Naeve, 1980).

In many types of vertebrate- and arthropod-cell cultures, flavivirus infection is not cytopathic. However, replication of flaviviruses in cultures of primary duck and chicken embryo cells, two lines of monkey kidney cells (Vero and $\mathrm{MK}_{2}$ ), a line of porcine kidney cells (PS), and baby hamster kidney cells results in the development of cytopathogenic changes of sufficient magnitude for use of these cells in plaque assays (Pfefferkorn and Shapiro, 1974; Trent and Naeve, 1980). Flavivirus infection of arthropod cells can be either cytocidal or noncytocidal (Mussgay et al., 1975; Trent and Naeve, 1980). Some flaviviruses induce syncytium formation in mosquito-cell lines (Igarashi, 1978, 1979; Ng and Westaway, 1980; Stollar, 1980). Flavivirus progeny produced by some types of arthropod cells have been found to differ phenotypically from the parental virus used to infect the culture. Dengue (type 2) virions produced by $A$. albopictus cells were found to lack hemagglutinating activity (Sinarachatanant and Olson, 1973). Ng and Westaway (1983) found that Kunjin virions, but not dengue (type 2) or JE virus, produced by A. albopictus 
cells lacked hemagglutinating activity. The A. albopictus-grown Kunjin virions were found to be unstable during routine purification procedures and to contain E protein that migrated more rapidly in polyacrylamide gels. These virions, which lacked hemagglutinating activity, were nevertheless able to bind to erythrocytes and block hemagglutination by the parental virus. The altered virion phenotype reverted to that of the parental virus after a single cycle of growth in Vero cells.

It has been shown that togaviruses enter their host cells by adsorptive endocytosis and are then delivered to intracellular vacuoles and lysosomes (see Chapter 4). The viral genome is subsequently released into the cytoplasm by a low-pH-induced fusion of the virion and lysosomal membranes (White et al., 1980). Under normal infection conditions, fusion between the cellular plasma membrane and the viral envelope does not occur. However, such a fusion event can be artificially triggered by addition of acidic medium (White et al., 1980). pH-dependent fusion has also been demonstrated for representative viruses of the rhabdovirus, myxovirus, and paramyxovirus families (White et al., 1981).

Extensive attempts to demonstrate a similar fusion phenomenon with WN virus in BHK cells have not succeeded (Brinton, Amato, and Gonda, unpublished data). Even though a number of different experimental conditions were tried, including attempts to fuse infected cells with each other or extracellular virus with uninfected cells, the precise requirements for flavivirus fusion were not achieved. Electron-microscopic data obtained by Gollins and Porterfield (1985) indicate that free flavivirions and virus-antibody complexes do enter the cell by an adsorptive endocytotic process which delivers them to intracellular vacuoles and lysosomes. Also, $\mathrm{pH}$-dependent flavivirus lysis has been demonstrated with extracellular virus and chick red blood cells with a $\mathrm{pH}$ optimum of 5.4 (Commack and Gould, 1985).

\section{A. Effect on Host-Cell Macromolecular Synthesis}

Host-cell macromolecular synthesis is not dramatically decreased by flavivirus infection. In one report, it was estimated that infection of BHK cells with SLE virus inhibited host protein synthesis $30 \%$ by $2 \mathrm{hr}$ after infection (Trent et al., 1969). The synthesis of high levels of cell proteins continues throughout the flavivirus replication cycle. Takehara (1971, 1972) reported that during JE virus or dengue virus infections in Vero cells, host-cell DNA synthesis and DNA-dependent RNA polymerase activity were reduced by $50-60 \%$ and $22-35 \%$, respectively, by $8 \mathrm{hr}$ after infection. However, Trent et al. (1969) reported that cellular DNA synthesis in BHK cells infected with SLE virus declined only at $18 \mathrm{hr}$ after infection, when virus-induced cytopathic effects became apparent. 


\section{B. Immune Enhancement}

Antibody-dependent enhancement of flavivirus infection has been demonstrated (Peiris and Porterfield, 1979; Halstead et al., 1980). This opsonic phenomenon occurs when cells bearing Fc receptors on their surfaces are infected with a flavivirus inoculum that has been mixed with antiviral antibody at concentrations insufficient to cause viral neutralization. Immune enhancement has been observed during infections of the murine macrophage cell lines, P388D1 (Peiris and Porterfield, 1979), and MK1 and Mm1 (Hotta et al., 1984), the human macrophage cell line U937 (Brandt et al., 1982), human peripheral-blood leukocytes (Halstead and O'Rourke, 1977), and human adherent monocytes (Brandt et al., 1979) with WN virus E101, YF virus 17D, and dengue 2 virus. Virus yields are enhanced by 20 -to 1000 -fold, depending on the strain of virus, cell type, and antibody used. Gollins and Porterfield (1984) have shown that the proportion of $\mathrm{WN}$ virus that bound to the surface of P388D1 cells and subsequently entered the cells was higher in the presence of subneutralizing concentrations of antiviral antibody than in their absence. The increased yields of virus were found to be due to an increased number of cells becoming productively infected in the presence of antiviral antibody (Peiris et al., 1981b).

It is clear that antibody enhancement is dependent on the presence of Fc receptors on the target-cell surface. Antibody enhancement could be successfully blocked by a monoclonal anti-Fc receptor antibody (Peiris et al., 1981 $\mathrm{a}, \mathrm{b})$, and neither $\mathrm{F}\left(\mathrm{ab}^{\prime}\right)_{2}$ fragments nor antiviral immunoglobulin $M(\operatorname{Ig} M)$ were found to mediate antibody enhancement (Halstead and O'Rourke, 1977; Peiris and Porterfield, 1982). In the absence of antibody, flavivirus particles presumably bind to a cell-surface receptor other than the Fc receptor (Daughaday et al., 1981). It is not known whether the uncoating processes differ during antibody-mediated and normal infections. However, data obtained by Gollins and Porterfield (1985) indicate that antibody-complexed WN virus enters the cell in the same manner as free WN virus. Antibody-mediated enhancement of YF virus 17D infection in P388D1 cells was not inhibited by concentrations of cytochalasin B that inhibited cellular phagocytosis and chloroquine also did not inhibit antibody enhancement of virus infection (Brandriss and Schlesinger, 1984).

Initially, antibody-enhancement experiments were carried out with hyperimmune sera. Species homology between the macrophage and the immunoglobulin was found not to be essential (Peiris and Porterfield, 1981). Antisera produced in rabbits, mice, humans, and sheep all enhanced flavivirus replication in murine P388D1 cells. However, in chick embryo fibroblast cultures, avian, but not mammalian flavivirus antisera, induced enhancement (Kliks and Halstead, 1980). Study of the antigenic specificity of antibody enhancement indicated that with flaviviruses, the 
phenomenon was group-reactive. Infection with a particular flavivirus could be enhanced with antisera specific for both closely related and distantly related flaviviruses (Peiris and Porterfield, 1982). In contrast, enhancement of alphaviruses occurs only with antisera specific for closely related viruses. Studies have subsequently been carried out with panels of flavivirus monoclonal antibodies using P388D1 and YF virus 17D. J. J. Schlesinger and Brandriss (1983) tested 13 monoclonal antibodies for their ability to induce antibody enhancement. All the monoclonal antibodies, whether they were YF virus 17D type-specific or flavivirus crossreactive, were found to enhance infection. The degree to which a particular monoclonal antibody enhanced a YF virus 17D infection did not correlate with its titer of neutralizing or hemagglutination-inhibition activity. Of 12 dengue 2 monoclonal antibodies tested during dengue 2 infections in U-937 cells, only the group-specific antibodies were found to mediate enhancement (Brandt et al., 1982). U-937 cells could not be infected by dengue 2 virus in the absence of antibody. Interestingly, these cells were susceptible to YF virus $17 \mathrm{D}$ replication in the absence of antibody. TBE virus infection in P388D1 cells was enhanced by 13 TBEvirus-complex-specific monoclonal antibodies, but not by a group-specific monoclonal antibody (Phillpotts et al., 1985). Using 5 monoclonal antibodies, Halstead et al. (1984) found that the same strain of dengue 2 virus (NGC) used by Brandt et al. (1982) was enhanced by one of two typespecific and two of three group-specific monoclonal antibodies in both U-937 and P388D1 cells. Seven different dengue 2 strains were also tested with the same 5 monoclonal antibodies (Halstead et al., 1984). Although all seven dengue 2 virus strains were neutralized by each of the 5 monoclonal antibodies in assays carried out in LLC-MK 2 cells, the viruses varied in their ability to be enhanced by the monoclonal antibodies during infections of P388D1 and U-937 cells. Two of the dengue 2 strains were enhanced by only 3 of the monoclonal antibodies, two by 4 of the antibodies, and three by all 5 of the antibodies. Experiments with monoclonal antibodies have not yet led to a clear definition of the characteristics of an immune-enhancing antibody.

Dengue viruses replicate in mononuclear phagocytes during human infection. In some instances, dengue virus infection induces a severe hemorrhagic disease termed "dengue shock syndrome" (Halstead, 1980, 1981, 1982; Sangkawibha et al., 1984). The factors that lead to the occurrence of dengue shock syndrome are not completely understood. However, it has been hypothesized that enhancing antibodies produced in an individual during a secondary infection with a dengue virus of a different serotype than the one responsible for the initial infection enhances viral replication in monocytes. These infected monocytes then become the targets of immune elimination, which is possibly T-cell-mediated, and release chemical mediators of shock and hemorrhage characteristic of dengue shock syndrome (Pang, 1983). Secondary infections with dengue 2 virus following primary infections with dengue 1 , dengue 3 , or dengue 
4 virus (in descending order of risk) appear to be most often associated with dengue shock syndrome in Asia (Sangkawibha et al., 1984). The extent of such an enhancement phenomenon might be expected to vary with the infecting virus strain, the specificity of the immune response, and the previous exposure history of the individual host (Halstead et al., 1983 , 1984). That immune enhancement may occur during in vivo infections has been indicated by the observation that cultures of peripheralblood leukocytes from dengue-immune donors yield higher titers of virus than do peripheral-blood leukocytes from normal donors after in vitro infection (Halstead et al., 1976). However, YF virus was found to grow equally well in leukocytes from immune and nonimmune donors (Liprandi and Walder, 1983).

Antibody-dependent enhancement of flavivirus infection has also been found to be mediated by a complement receptor (Cardosa et al., 1983). In the presence of fresh normal serum, anti-WN virus IgM was shown to enhance WN virus infection of P388D1 cells. Further, this enhancement could be blocked by a monoclonal antibody, M1/70, that is known to inhibit the binding of the $\mathrm{C} 3$ complement component. The two types of antibody enhancement (Fc-and complement-receptor-mediated) may function in a synergistic manner. Some subclasses of IgG also fix complement, and many types of cells (such as erythrocytes, lymphocytes, neutrophils, monocytes, macrophages, and kidney epithelial cells) can express complement receptors on their surfaces.

In other studies, treatment of mouse peritoneal cultures with bacterial lipopolysaccharide, phytohemagglutinin, bacterial cell walls, peptidoglycans, or a water-soluble polymer of peptidoglycan subunits for 3 days prior to dengue 2 virus infection resulted in an increased production of virus (Hotta et al., 1983). The increased yield appeared to correlate with an increase in the number of virus-infected cells. The treated macrophages were found to phagocytize latex particles more efficiently than untreated cells. These authors suggest that dengue 2 virus infection can be established by virus taken up by phagocytosis.

\section{VIRAL MORPHOGENESIS}

Progeny virions are readily observed in thin sections of flavivirusinfected cells by $8-12 \mathrm{hr}$ after infection within the cisternae of endoplasmic reticulum vesicles. These vesicles are located in the perinuclear area of the cytoplasm (Murphy, 1980; Westaway, 1980). Hypertrophy of the rough and smooth endoplasmic reticulum and in some areas the Golgi membranes is a characteristic feature of flavivirus infections (Fig. 4A and B). Dense accumulations of convoluted microtubules develop near the nucleus (Fig. 4C). These mesh-like structures are often located near intracellular progeny virions, and it has been suggested that they may be somehow involved in virus maturation (Westaway, 1980). Mature virions 

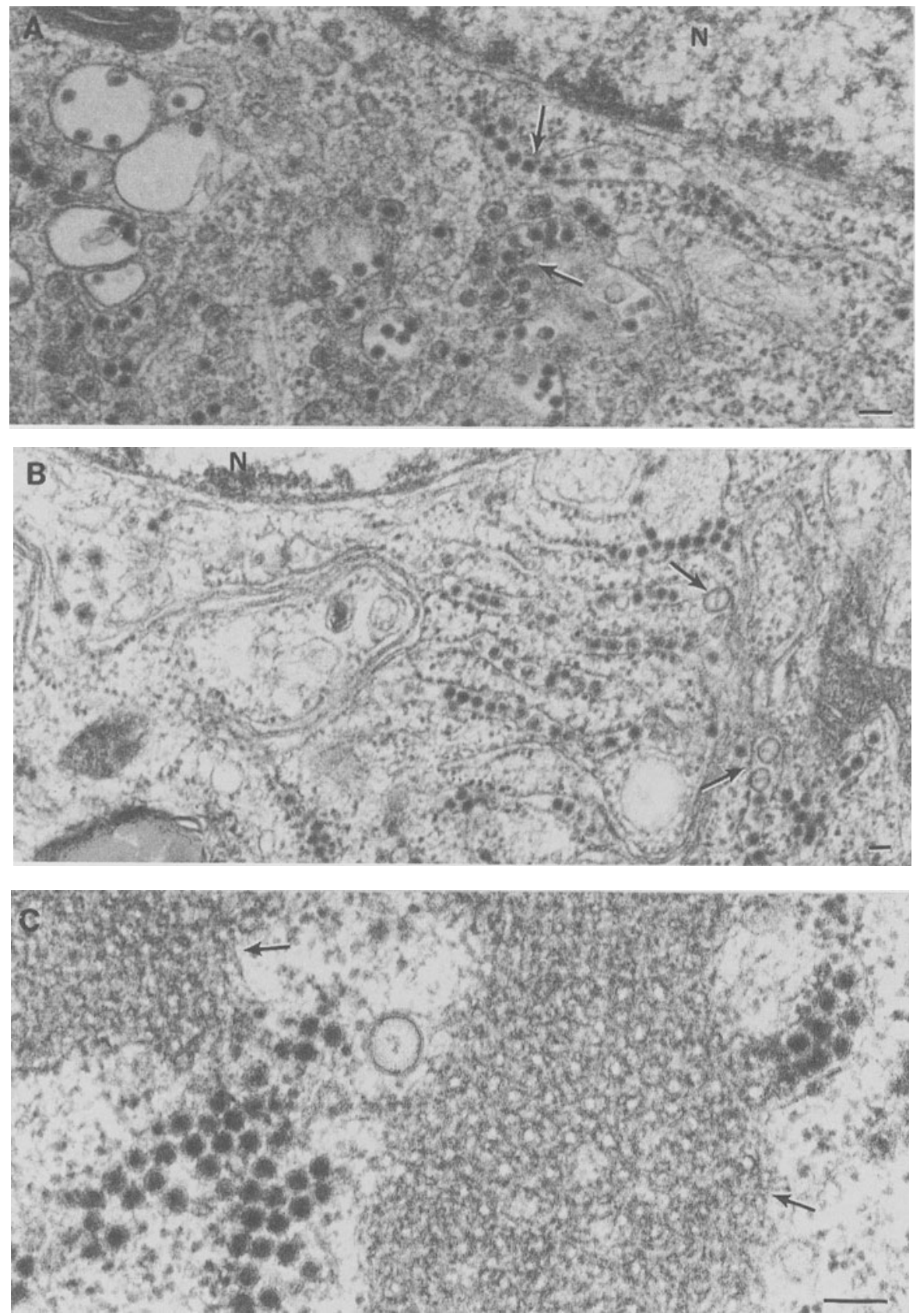

FIGURE 4. Electron micrographs of virus-specific structures seen in thin sections of BHK21/WI2 cells $18 \mathrm{hr}$ after infection with WN virus E101 at a multiplicity of infection of 5 . (A) Virions are seen within cisternae of the endoplasmic reticulum in the perinuclear area of the cell. $\times 43,000$. (B) Round lucent, double-membrane vesicles are often seen in areas of virus maturation. These vesicles have internal reticular webs and are located within 
accumulate in vacuoles with smooth membranes, within the Golgi complex, and in vesicles with electron-dense particles, presumably ribosomes, along their outer surfaces. Cytoplasmic accumulations of nonenveloped nucleocapsids are not observed in flavivirus-infected cells, and nucleocapsids cannot be isolated from infected cells. Intracellular virions have been reported to be composed of E, C, and a glycosylated nonstructural protein instead of the M protein (Shapiro et al., 1972a-c, 1973). In JEvirus-infected cells, this nonstructural protein was designated gp17-19. Recent nucleotide sequence data indicate that in YF virus, the nonstructural protein of this molecular weight is not glycosylated, but that a 19$23 \times 10^{3}$ dalton protein is the glycosylated precursor of the M protein that is found in extracellular virions (see Chapter 10). No direct evidence for envelopment of flaviviruses by an intracellular budding process has been obtained by either thin-section or freeze-fracture studies of infected cells (Murphy et al., 1968; Demsey et al., 1974; Westaway, 1980; Murphy, 1980). Leary and Blair (1980) have suggested that virion assembly may occur within lucent vesicles budded from cytopathic vacuoles. Intracellular virions have been observed to exit from infected cells by at least two routes. The lamellae of smooth membranes in Kunjin-infected cells have been found to open directly to the exterior (Westaway, 1980). Viruscontaining vesicles have been observed to move to the periphery of the cytoplasm and fuse with the plasma membrane (Filshie and Rehacek, 1968; Dalton, 1972). The final processing of the M protein apparently occurs during the release of virions from cells. The efficiency of flavivirus release from infected cells can be enhanced by addition of $40-80 \mathrm{mM}$ $\mathrm{MgCl}_{2}$ to the culture medium at $10 \mathrm{hr}$ after infection (Matsumura et al., 1972). In mosquito salivary gland cells, SLE virions have been reported to exit from the apical end of the cells by means of membrane fusion or a localized breakdown of the plasma membrane (Whitfield et al., 1973). Virions released by cells lysed during cytocidal infections often remain enclosed within membrane vesicles (Murphy et al., 1968; Sriurairatna et al., 1973; Calberg-Bacq et al., 1975).

\section{A. Intracellular Sites of Viral Macromolecular Synthesis}

In flavivirus-infected cells, essentially all the virus-specified protein present appears to be associated with detergent-labile membranes (Shapiro et al., 1973). No preferred cellular membrane site was observed for the incorporation of either the $\mathrm{E}$ protein or the $\mathrm{C}$ protein, since all the flavivirus proteins were present in all the cellular membrane fractions separated on discontinuous sucrose gradients by the method of Caliguiri and Tamm (1970) (Shapiro et al., $1972 \mathrm{a}-\mathrm{c}$; Kos et al., 1975; Stohlman

cisternae of endoplasmic reticulum. $\times 27,500$. (C) Cytoplasmic membranes often proliferate in infected cells to form meshlike structures. $\times 98,500$. (N) Nucleus. Scale bars: $200 \mathrm{~nm}$. 
et al., 1975; Boulton and Westaway, 1976). The incorporation of the viral proteins into the plasma membranes was unexpected, since there is no evidence that the plasma membrane plays any role in flavivirus replication or maturation. Recently, however, J. J. Schlesinger et al. (1986) were unable to detect the E protein of YF virus on the surfaces of infected neuroblastoma cells using 14 anti-E monoclonal antibodies. The nonstructural protein gp44-48 (NV3) was readily detected on the surfaces of the infected neuroblastoma cells. Immunofluorescent studies indicate that within the infected cell, the viral E protein first accumulates around the nucleus in a narrow band that progressively broadens into the cytoplasm with time after infection.

Studies utilizing various cell-fractionation methods to attempt to identify the intracellular membrane sites of viral RNA and protein synthesis have provided equivocal results. Westaway and $\mathrm{Ng}$ (1980) found that viral RNA labeled by a 10-min pulse of $\left[{ }^{3} \mathrm{H}\right]$ uridine was located primarily in the light membrane fraction obtained from the cytoplasm of infected cells. The incorporated $\left[{ }^{3} \mathrm{H}\right]$ uridine in these membranes was present in an RNase-resistant form. RNase-sensitive viral RNA was found to accumulate on heavy membrane fractions obtained from the nuclear pellet by shearing and nonionic detergent treatment after a 3 -hr pulse of $\left[{ }^{3} \mathrm{H}\right]$ uridine. In previous studies, dengue 2 virus RNA and protein synthesis were both found to occur on the same dense membrane fraction (Stohlman et al., 1975). In other studies, when cells were disrupted with nonionic detergents such as NP40, no viral RNA was found to be associated with outer nuclear membranes (Naeve and Trent, 1978; Westaway, 1977). The use of detergent to lyse the plasma membrane could also result in the release of viral replication complexes and polysomes from membranes as well as the release of viral cores from intracellular virions (Westaway and $\mathrm{Ng}, 1980$ ).

Although it is clear that flavivirus protein and RNA synthesis as well as virion assembly occur in the perinuclear region of the infected cell, conflicting results have been obtained as to whether the host-cell nucleus is required during any phase of the virus replication cycle. JE-virus-like particles were reported to have been observed within the nuclei of infected cells (Yazuzumi et al., 1964), and JE virus replication was reported not to occur in cells enucleated by cytochalasin B prior to infection (Kos et al., 1975). However, virus replication did continue, but at a reduced level, in cells enucleated $4 \mathrm{hr}$ or later after infection. Cordycepin, an inhibitor of polyadenylation, decreased both JE virus and SLE virus replication by $50-60 \%$ when added to cells up to $9 \mathrm{hr}$ after infection (Kos et al., 1976; Brawner et al., 1979|. The apparent effect of cordycepin on flavivirus replication could be a secondary effect of decreased cell viability or might reflect the involvement of host proteins in flavivirus replication. Mitomycin C, an inhibitor of DNA synthesis, had no effect on JE virus replication (Leary and Blair, 1983). Disruption of microtubules by vinblastine treatment of cells reduced Kunjin virus replication by at least 
10-fold ( $\mathrm{Ng}$ et al., 1983). Conflicting results have been obtained with actinomycin D (Trent and Neave, 1980). Some studies indicated that flavivirus replication could be reduced by addition of $1 \mu \mathrm{g} / \mathrm{ml}$ or more of actinomycin D during the first $9 \mathrm{hr}$ after infection (Brawner et al., 1979). However, when actinomycin D was added for a few hours prior to infection, after the latent phase, or at low doses, flavivirus replication was unaffected. More recent studies by Leary and Blair (1983) indicate that the apparent inhibition of flavivirus replication by actinomycin D may have been a secondary result of a progressive loss of cellular viability due to drug toxicity. The much longer growth cycle of flaviviruses requires that cells remain viable for $20-30 \mathrm{hr}$ to obtain normal maximal viral yields. Addition of $5 \mu \mathrm{g} / \mathrm{ml}$ of actinomycin D to the culture medium for 2-hr periods from 1 to $6 \mathrm{hr}$ after infection had no effect on the yield of JE virus harvested at $24 \mathrm{hr}$ after infection (Leary and Blair, 1983). No immunofluorescence has been detected in the nuclei of infected cells with either anti-double-stranded RNA (dsRNA) antibody or antiviral antibody. To date, there is no evidence of a specific nuclear involvement in flavivirus replication. However, the outer nuclear membranes do provide sites for flavivirus replication and maturation.

Since the two largest nonstructural proteins (p96 and p67), which presumably function as viral RNA-dependent RNA polymerases (Westaway, 1977), are found associated with all the cellular membrane fractions, little is known about the intracellular location of the active viral replication complexes. However, flavivirus polymerase activity has consistently been found to be higher in cell fractions enriched for outer nuclear membranes (Zebovitz et al., 1974; Chu and Westaway, 1984; Grun and Brinton, 1986a). In Kunjin-virus-infected cells, the rough endoplasmic reticulum in the perinuclear region of the cell has been observed to change from a fine network to a coarse one during the first 4-12 $\mathrm{hr}$ of infection (Ng et al., 1983). Using an antibody specific for dsRNA, Ng et al. (1983) found that immunofluorescence in Kunjin-virus-infected cells was distributed in a fine network in the perinuclear region. The network contained many foci. Ribosome like particles are often observed to stud the cytoplasmic side of the vesicles within which mature flavivirions accumulate in infected cells (Matsumura et al., 1971). Autoradiographs of actinomycin-D-treated, JE-virus-infected cells labeled with $\left[{ }^{3} \mathrm{H}\right]$ uridine for 10-30 min showed an increasing accumulation of radioactivity on rough endoplasmic reticulum (Takeda et al., 1978; Lubiniecki and Henry, 1974). These results indicate that the flavivirus proteins may be synthesized on membranes at the site of viral RNA synthesis and virion maturation.

\section{VIRAL RNA SYNTHESIS}

After uncoating, the flavivirus genome RNA must first be translated to provide the viral replicase and transcriptase activities needed for RNA 
synthesis. The genome $40 \mathrm{~S}$ RNA is the initial template, from which a minus-strand complementary RNA is synthesized. This minus strand then becomes the template for the synthesis of progeny plus-strand RNAs. The newly synthesized plus-strand 40 S RNAs are utilized as templates for the production of minus-strand RNAs, as messenger RNA (mRNA) for the translation of viral proteins, and as molecules for encapsidation into progeny virions. It is interesting to note that among the plus-strand RNA animal viruses, only picornaviruses and flaviviruses produce no subgenomic mRNAs and have the polymerase gene(s) at the $3^{\prime}$ end of the genome coding region.

Intracellular viral RNA synthesis has been detected as early as $3 \mathrm{hr}$ after infection (Takeda et al., 1978). Trent et al. (1969) found that flavivirus RNA synthesis was biphasic, with a small peak of synthesis occurring at $6 \mathrm{hr}$ after infection and then a steady increase in RNA synthesis beginning by $13 \mathrm{hr}$ after infection. The majority of the viral RNA produced during infection is plus-strand $40 \mathrm{~S}$ genome RNA (Stollar et al., 1967). It has been estimated that the ratio of plus- to minus-strand RNAs produced is 10:1 (Cleaves et al., 1981).

Several types of flavivirus-specific RNAs have been identified in infected cells. In addition to single-stranded $40 \mathrm{~S}$ genome RNA, RNaseresistant RNA (20-22 S) and RNA that is partially (50-70\%) resistant to RNase (20-28 S) have been observed in cells infected with a number of different flaviviruses (Stollar et al., 1967; Trent et al., 1969; Zebovitz et al., 1972; Wengler et al., 1978; Cleaves et al., 1981; Chu and Westaway, 1985). Pulse-chase studies showed that $\left[{ }^{3} \mathrm{H}\right]$ uridine appeared first in the 20-28 S RNA and subsequently in the 40 S RNA (Cleaves et al., 1981). These studies demonstrated that the 20-28 S RNA represented replicative-intermediate (RI) RNA. It was further suggested that the RNaseresistant 20-22 S RNA was a replicative-form (RF) RNA (Cleaves et al., 1981). The RF RNA was soluble in $2 \mathrm{M} \mathrm{LiCl}$ and, when rebanded on a sucrose gradient after $\mathrm{LiCl}$ fractionation, migrated as a single sharp band. The RI RNA was not soluble in $\mathrm{LiCl}$ and migrated heterogeneously in gradients. Although these studies clearly suggested that there was a precursor-product relationship between the heterogeneous 20-28 S RI RNA and the $40 \mathrm{~S}$ virion RNA, the precise role of the RF RNA in the replication process has not been delineated. The RF molecules were labeled during the experimental pulse periods. Complete denaturation of the 20-28 S heterogeneous RNA resulted in a molecular-weight shift, indicating that the RI RNA was composed of genome-length RNA and a continuum of subgenomic length RNAs. In contrast, the RF RNA contained only genome-length RNA (Cleaves et al., 1981). The 30-50\% RNase susceptibility of the radioactivity incorporated into the RI RNA during pulse-chase experiments carried out at $42 \mathrm{hr}$ after infection was attributed to incomplete base-pairing due to an excess of plus-strand products over minus-strand templates (Cleaves et al., 1981). Calculation of the number of nascent growing strands per dengue $2 \mathrm{RI}$ structure indi- 
cated that there were 5 per RI RNA, and it was estimated that 12-15 min is needed for the completion of a nascent chain (Cleaves et al., 1981).

Somewhat different results have been reported recently by $\mathrm{Chu}$ and Westaway (1985), using Kunjin-infected cells. Isotope was incorporated only into RF and RI RNAs within a 10-min pulse period, but after a 10to 20-min chase, the majority of the radioactivity was found in progeny genome RNA. In contrast to the findings of Cleaves et al. (1981), Chu and Westaway (1985) observed a relatively high RNase resistance of the flavivirus RI RNA, rapid labeling of the RF RNA, and slow appearance of label in $40 \mathrm{~S}$ RNA. Chu and Westaway (1985) have proposed a model for flavivirus plus-strand RNA synthesis that hypothesizes that the RF RNA is a double-stranded molecule which acts as a recycling template for semiconservative and asymmetric replication. According to their model, plus-strand RNA synthesis is initiated on the minus strand template of an RF molecule in a semiconservative manner. The synthesis of the new plus strand proceeds rapidly, converting the RF to an RI RNA. A short delay occurs in the release of the displaced strand, so that the majority of RI RNAs at any one time consist of the minus-strand template, one displaced completed plus strand, and one base-paired almost completed nascent plus strand. When release of the displaced plus strand does occur, the incomplete one finishes, but remains attached along its entire length to the minus-strand template and an RF molecule is regenerated. According to this model, during a pulse-chase experiment, labeled $40 \mathrm{~S}$ plus-strand RNA would first be released only after the second round of synthesis on any particular minus-strand template had occurred. This model does not explain how the initial minus strand is initiated from the genome of the infecting virion, nor does it explain how selective amplification of plus-strand synthesis is accomplished.

Minus-strand synthesis may be carried out by a different mechanism and by a different enzyme complex than plus-strand synthesis. It is currently not known which of the viral nonstructural proteins provide the replicase functions or whether the initiation and elongation activities reside in the same or different proteins. Part of the evidence provided by Chu and Westaway (1985) in support of their replication model is the observation that only labeled 40 S RNA was detected when RI RNAs were totally denatured. However, Cleaves et al. (1981) did observe the production of labeled, heterogeneous small nascent RNAs under similar experimental conditions. In addition, RI RNAs synthesized in vitro by a nuclear extract of Kunjin-virus-infected cells contained heterogeneous ssRNA with molecular weights ranging from 0.5 to $4.2 \times 10^{6}$ (Chu and Westaway, 1985). RI RNAs produced in vitro by WN-infected cell extracts also contain heterogeneous subgenomic-sized RNAs as well as 40 S RNA (Grun and Brinton, unpublished data). These data indicate that the rate of synthesis of nascent plus strands is not so rapid as to preclude detection of partially completed nascent strands after denaturation of flavivirus RI RNAs, as was suggested by Chu and Westaway (1985). 
Flavivirus in vitro polymerase activity has been detected in crude infected cellular extracts by several laboratories (Zebovitz et al., 1974; Takeda et al., 1978; Brawner et al., 1979; Cardiff et al., 1973; Qureshi and Trent, 1972; Chu and Westaway, 1985; Grun and Brinton, 1986a and b). Polymerase activity was found to be reduced by treatment with nonionic detergents (Cardiff et al., 1973), indicating an association of the active replication complexes with membranes. Polymerase activity is associated with cytoplasmic membranes, the mitochondrial fraction, and nuclear-associated membranes. However, activity was consistently found to be highest in nuclear-associated membranes (Zebovitz et al., 1974; Takeda et al., 1978; Chu and Westaway, 1985; Grun and Brinton, 1986a). This finding is not unexpected, since the majority of viral RNA synthesis occurs in the perinuclear region of infected cells (Westaway, 1980). Qureshi and Trent (1972) isolated a $250 \mathrm{~S}$ "replication complex" from SLEinfected cells by treatment of cell extracts with EDTA. These complexes contained pulse-labeled (15 min) genome RNA and 20-26 S partially RNase-resistant RNA as well as polymerase activity.

Although a number of laboratories have successfully detected in vitro flavivirus polymerase activity in infected cell extracts, limited information has been reported on the optimal reaction conditions. Optimal conditions for WN virus polymerase activity in cell-free BHK21/WI2 extracts have recently been determined (Grun and Brinton, 1986b). Further experiments are necessary to determine whether these conditions are also optimal for other flaviviruses and cell extracts. By analogy with other RNA virus polymerases, it seems likely that the two largest nonstructural proteins, p96 and p67, do have polymerase function, and antibody to p67 has been found to inhibit in vitro polymerase activity (Brinton and Grun, unpublished data).

RNA synthesis must be initiated on the $3^{\prime}$ ends of both the plusstrand and the minus-strand RNAs. Since the extent of synthesis of these two strands is regulated quite differently during the course of infection, it is not unreasonable to postulate that different proteins or protein complexes may be involved in initiation of synthesis on the plus- and minusstrand RNAs. Once RNA synthesis has been initiated on a template, an elongation activity is required to complete the nascent strand. Further work is needed to determine which viral proteins, individually or in complex, provide these various functions. Investigation of the involvement of host-cell proteins in flavivirus RNA synthesis is also of interest, since host factors have been reported to be involved in viral RNA synthetic functions during infections with picornaviruses and several RNA bacteriophages (Zinder, 1975; Dasgupta et al., 1980).

The RNA products synthesized in in vitro polymerase reactions sediment heterogeneously between 20 and $28 \mathrm{~S}$ on sucrose gradients (Zebovitz et al., 1974; Cardiff et al., 1973). Zebovitz et al. (1974) found this RNA to be resistant to RNase treatment, while Cardiff et al. (1973) found it to be sensitive. More recently, Chu and Westaway (1985) reported that 
both RI and RF RNA were labeled during an in vitro polymerase reaction, only trace amounts of labeled free ssRNA was detected. We have found that RI RNA is more extensively labeled than RF RNA and that significant amounts of $40 \mathrm{~S}$ RNA are labeled and released during in vitro reactions with WN-infected BHK cell extracts /Grun and Brinton, 1986a and b). Although cell extracts made from WN-infected cells $16 \mathrm{~h}$ after infection primarily synthesize plus-strand genome RNA from minusstrand templates, addition of 1 to $2 \mu \mathrm{g}$ of exogenous genome RNA to the in vitro reactions stimulated polymerase activity by two-fold (Grun and Brinton, 1986b). This observation indicates that RNA synthesis can be initiated in vitro from the added genomic RNA templates.

Small intracellular (8-15 S) RNAs have also been observed in actinomycin-D-treated flavivirus-infected cells (Zebovitz et al., 1972, 1974; Takeda et al., 1978; Naeve and Trent, 1978). Wengler et al. (1978) reported that three sizes of virus-specific low-molecular-weight flavivirus RNAs could be detected. A $5 \times 10^{4}$ dalton species was synthesized in both $A$. albopictus and BHK-21 cells infected with Uganda S virus. Two lowmolecular-weight RNAs $\left(6.5 \times 10^{4}\right.$ and $\left.4.2 \times 10^{4}\right)$ were observed in $\mathrm{WN}$ infected BHK cells, while only the $6.5 \times 10^{4}$ dalton RNA was synthesized in the WN-infected mosquito cells. Further study of the $6.5 \times 10^{4}$ dalton RNA revealed that it was of plus-strand polarity, not "capped" at its 5 ' end, and did not contain a 3' poly(A) sequence. The mode of synthesis of these small virus-specific RNAs is not known. These RNAs may represent prematurely terminated transcripts or defective interfering RNAs (see Section VIII). If they are not defective interfering RNAs, it is possible that these small RNAs may play an as yet undetermined role in flavivirus replication.

\section{VIRAL PROTEIN SYNTHESIS}

At all times after infection, the only viral RNA found in polysomes purified from flavivirus-infected cells is the full-sized genome RNA (Naeve and Trent, 1977; Cleaves and Schlesinger, 1977; Trent and Naeve, 1980). No poly(A) sequence has been found at the 3 ' end of progeny plusstrand RNAs isolated from polysomes. All the available evidence indicates that the $40 \mathrm{~S}$ RNA that serves as the only viral messenger RNA is identical to the genome RNA that is encapsidated into virions. In vitro translation of virion RNA indicated that translation begins at a single initiation site (Wengler et al., 1979; Svitkin et al., 1981; Monckton and Westaway, 1982). However, only viral structural protein polypeptides were produced by in vitro translation, suggesting that the structural proteins were encoded at the $5^{\prime}$ end of the genome. This gene arrangement is similar to that of the picornaviruses, rather than that of the alphaviruses (E. G. Strauss and J. H. Strauss, 1983). The nucleotide sequence of the genome RNA of YF virus demonstrates that the structural genes are ar- 
ranged from the $5^{\prime}$ end of the RNA in the order 5'-C-M-E (Rice et al., 1985). In addition, the YF virus nucleotide sequence was found to contain a single, very long open reading frame. $\mathrm{N}$-terminal amino acid sequences have been obtained for the E, C, M, and gp 19-23 (precursor of $M$ ) proteins of several flaviviruses (Bell et al., 1985). The demonstration that these viral proteins were not blocked and did not have a methionine at their $\mathrm{N}$ termini suggested that they were produced from a polyprotein precursor by posttranslational cleavage. Although there has been some evidence that a large $(200,000$ - to 300,000 -dalton) viral specific precursor is produced in flavivirus-infected cells, a rigorous demonstration of such a precursor polyprotein has not yet been reported. The posttranslational cleavage of the flavivirus polyprotein precursor in infected cells must occur very rapidly and with relatively few large intermediate precursors, since pulse-chase experiments have failed to demonstrate transient precursor polypeptides (Westaway, 1977, 1980; Westaway et al., 1984). The viral-specific proteins detected in infected cells each appear to be unique by peptide mapping and together do not exceed the coding capacity of the flavivirus genome. Pactamycin mapping studies indicated that viral proteins were completed in the order of their size (Westaway, 1977). Rapid labeling of all viral proteins was observed when protein synthesis was reinitiated after release of a high-salt block (Westaway, 1977). On the basis of these data, Westaway $(1977,1980)$ proposed that the translation of each of the flavivirus proteins is separately initiated and terminated on the genome mRNA. Data from UV mapping experiments suggested that the flavivirus genome RNA contains two separate translational units (Westaway et al., 1984). A further discussion of these observations and the flavivirus translational strategy can be found in Chapter 10.

Since flavivirus infection does not appreciably inhibit host-cell protein synthesis, it is necessary to treat infected cells with actinomycin D or cycloheximide (Trent and Qureshi, 1971; Shapiro et al., 1971), to synchronize translation reinitiation by high-salt treatment (Westaway, 1977), or to use a double-label subtraction method (Westaway, 1973) to detect the intracellular synthesis of viral-specific proteins. Nine virusspecified proteins have been identified in $\left[{ }^{35} S\right]$ methionine-labeled extracts from flavivirus-infected cells (Fig. 5; Rice et al., 1985). Each of these proteins appears to be unique by peptide mapping. One of these proteins is the structural E glycoprotein, gp51-59 (V3), and one a nonstructural

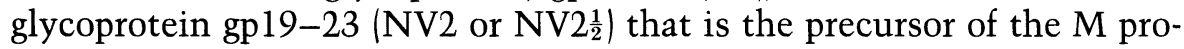
tein. The M protein is not found in infected cells, but only in extracellular virions (Shapiro et al., 1972a-c; Westaway, 1980). The form of the C protein [p13-16 (NV1 $\left.\left.\frac{1}{2}\right)\right]$ present intracellularly migrates slightly faster in polyacrylamide gels than the $\mathrm{C}$ protein (V2) isolated from virions (Wright and Westaway, 1977). One additional nonstructural protein, gp44-48 (NV3), is also glycosylated. Five further nonglycosylated, nonstructural proteins usually detected in flavivirus-infected cells are p91-98 (NV5),

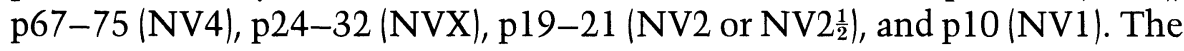




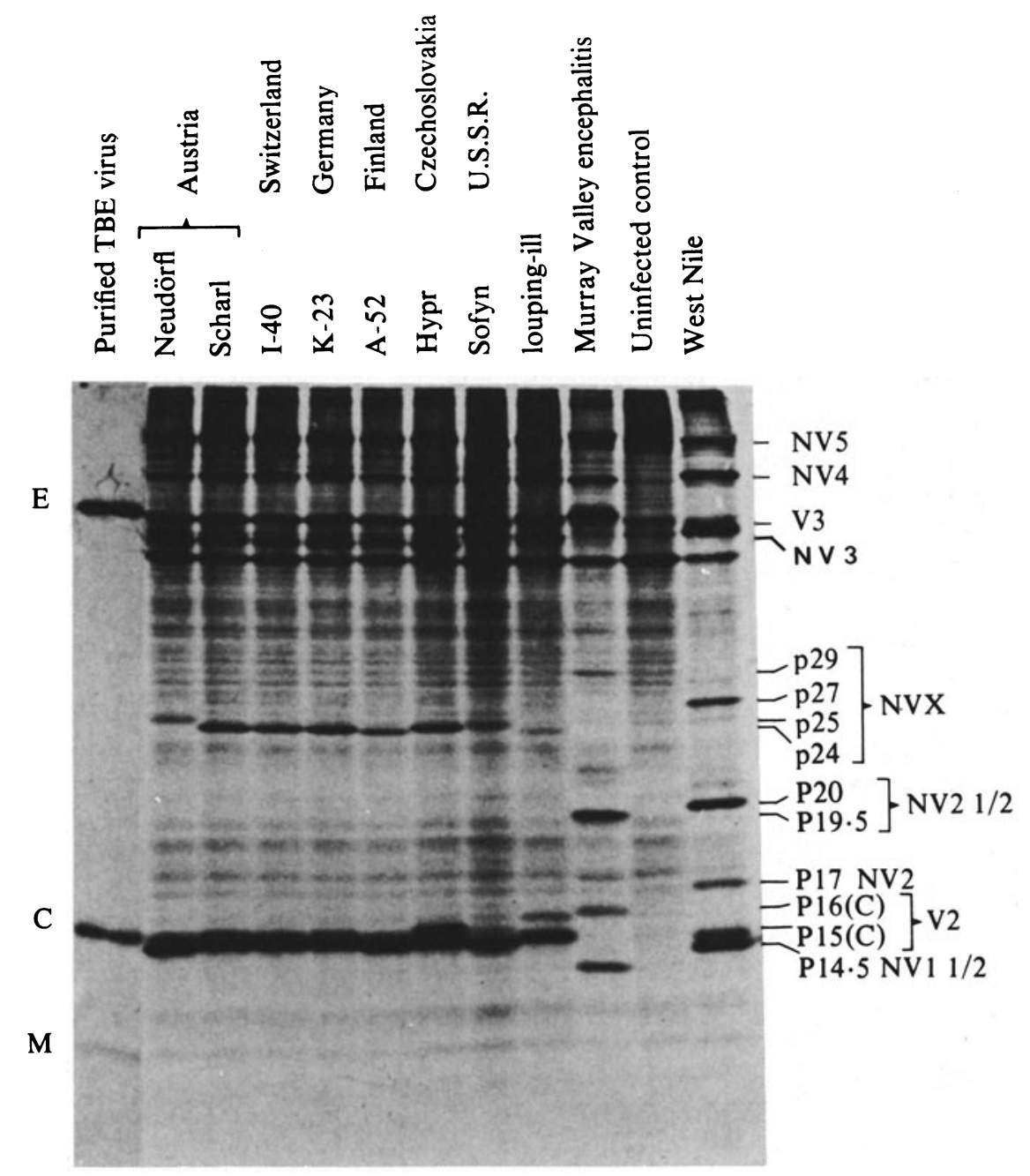

FIGURE 5. Intracellular flavivirus-specific proteins. $\left[{ }^{35} \mathrm{~S}\right]$ Methionine-labeled cell extracts from primary chick embryo cells infected with various flaviviruses were analyzed on a $17 \%$ SDS-polyacrylamide gel. Proteins were labeled from 24 to $30 \mathrm{hr}$ after infection. Purified TBE virions and an uninfected cell extract were used as controls. From Heinz and Kunz (1982).

former designation of each protein is indicated in parentheses (Westaway et al., 1980). Some confusion has resulted because all the small intracellular proteins are not always detected in radioactively labeled infected cell extracts. Also, the migration of some of these proteins varies with the host cell and flavivirus used. Identification of NV2 and NV2 $\frac{1}{2}$ has been especially difficult. On the basis of new information obtained from the sequencing and mapping of the YF virus, 17D, genome RNA, a new nomenclature for the flavivirus nonstructural proteins has been proposed (see Chapter 10). 
The functions of the majority of the nonstructural proteins are not currently known. It is presumed that the two largest proteins function in polymerase complexes. The gp44-48 (NV3) protein has recently been identified as the soluble complement-fixing antigen, which is released by flavivirus-infected cells (G. W. Smith and Wright, 1985). Immunization of mice with gp44-48 (NV3) obtained from YF-virus-infected cells was found to provide protection against virus challenge in the absence of neutralizing antibody (J. J. Schlesinger et al., 1986). Complement-fixing monoclonal antibodies to gp44-48 were also protective, apparently through complement-mediated cytolysis of infected cells expressing gp44-48 on their plasma membranes (J. J. Schlesinger et al., 1986).

Comparisons of the migration patterns in polyacrylamide gels of proteins produced by various flaviviruses indicate that there is significant variation in the apparent molecular weights of both structural and nonstructural proteins (Shapiro et al., 1971; Trent and Qureshi, 1971; Westaway, 1973; Westaway and Shew, 1977; Heinz and Kunz, 1982; Wright et al., 1983) (Fig. 5). It is interesting that serologically distinct flaviviruses show heterogeneity in the molecular weights and peptide maps of their two largest nonstructural proteins, p91-98 and p67-75, as well as in their virion E glycoprotein, gp51-59 (Heinz and Kunz, 1982). In the case of togaviruses and certain plant viruses, viral polymerase protein sequences have been found to be highly conserved even during divergent virus evolution (Ahlquist et al., 1985). Comparison of the sequences of the two largest nonstructural proteins of various flaviviruses will indicate the extent of conservation (see Chapter 3).

\section{GENETICALLY CONTROLLED RESISTANCE TO FLAVIVIRUSES}

A gene coding for resistance to flavivirus-induced disease has been found to segregate within several mouse populations. Heritable susceptibility to YF virus was first reported by Sawyer and Lloyd (1931) in Rockefeller Institute mice. From the same outbred mouse colony, Webster (1933) developed a resistant line [(BRVR) bacteria-resistant, virus-resistant] by breeding mice that survived infections with louping ill or SLE virus. An inbred susceptible mouse strain (BSVS) was also developed by Webster. Sabin $(1952 \mathrm{a}, \mathrm{b})$ subsequently demonstrated that Princeton Rockefeller Institute (PRI) mice were resistant to YF virus, but susceptible to other types of viruses. Using PRI mice as the source of the resistance gene, a third inbred resistant strain, $\mathrm{C} 3 \mathrm{H} / \mathrm{RV}$, was developed that is congenic to susceptible $\mathrm{C} 3 \mathrm{H} / \mathrm{He}$. A study of wild mice obtained from California and Maryland demonstrated the presence of the flavivirus resistance gene among wild mouse populations (Darnell et al., 1974).

In all instances, flavivirus resistance is inherited as an autosomal dominant allele. Since virus infections often induce permanent impair- 
ment or death in their hosts, it is not unreasonable to expect that they could exert a selective pressure for the maintenance of host alleles that fortuitously confer a reduced susceptibility to viral diseases in host populations (Brinton and Nathanson, 1981; Brinton et al., 1984). To date, murine genes that can specifically influence the outcome of infections with members of three families of DNA viruses and five families of RNA viruses have been identified (Brinton et al., 1984). Each of these resistance genes influences infections with only one family of viruses or, in some cases, one strain of virus. This virus-specific feature distinguishes genetically controlled resistance from other types of host defense mechanisms and implies that the product of each resistance gene affects a step in the infection cycle characteristic of only one type of virus. Such an interaction could occur at any step during the infectious process.

Flaviviruses can replicate in mice that possess the resistance allele, but in resistant mice, virus titers in tissues are lower (by 1000- to 10,000fold) than in susceptible mice, and the spread of infection is slower and usually self-limiting. Factors such as the age of the host, the degree of virulence of the infecting flavivirus, and the route of infection have been found to influence the extent of the phenotypic expression of resistance. Although resistant mice can be killed by large doses of virulent flaviviruses administered by the intracerebral route or by infection after experimental immunosuppression, a reduced production of infectious virus is always observed in the brains of $\mathrm{C} 3 \mathrm{H} / \mathrm{RV}$ mice as compared to the brains of similarly treated susceptible $\mathrm{C} 3 \mathrm{H} / \mathrm{He}$ mice. The titer of $\mathrm{WN}$ virus per gram of brain is shown in Fig. 6A for adult mice sacrificed on successive days after an intracerebral injection with $10^{5.5}$ plaque-forming units (PFU) of WN virus E101. Under these conditions of infection, all the $\mathrm{C} 3 \mathrm{H} / \mathrm{He}$ mice died on day 4 , while about $50 \%$ of the $\mathrm{C} 3 \mathrm{H} / \mathrm{RV}$ mice died on day 7. The titer of virus in $\mathrm{C} 3 \mathrm{H} / \mathrm{RV}$ brains rose somewhat on day 7 in mice that were moribund. Even though resistant mice produce less virus than susceptible mice, a functioning immune system is required for the survival of infected resistant animals. The levels of neutralizing antibody and interferon that are produced in response to flavivirus infection are higher in susceptible animals than in resistant ones, correlating with the higher titers of virus synthesized in susceptible animals. Interferon is not specifically involved in mediating the expression of flavivirus resistance, as is the case with resistance to myxoviruses (Brinton et al., 1982). Other types of viruses replicate equally well in resistant and susceptible cell cultures and animals.

Cultured cells obtained from resistant mice produce lower yields of flaviviruses than do comparable cultures obtained from susceptible animals, even though the cells in both cultures are equally infectable (Fig. 6B) (Webster and Johnson, 1941; Darnell and Koprowski, 1974). This difference in virus yield is observed with embryo fibroblasts, kidney cells, brain cells, and macrophages. Also, the differential ability to produce flaviviruses was maintained by established lines of SV40-transformed em- 

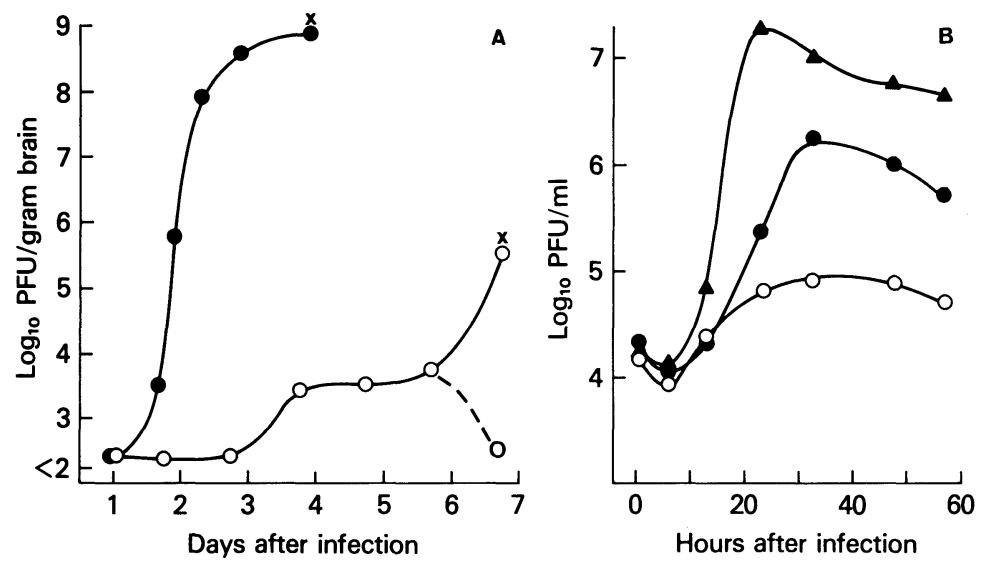

FIGURE 6. Growth of West Nile virus, strain E101. (A) In the brains of adult susceptible $\mathrm{C} 3 \mathrm{H} / \mathrm{He}(\bullet)$ and resistant $\mathrm{C} 3 \mathrm{H} / \mathrm{RV}(\mathrm{O})$ mice. Animals were injected with $10^{5.5}$ plaque-forming units (PFU) of virus by the intracerebral route. With this dose of virus, $100 \%$ of the $\mathrm{C} 3 \mathrm{H} / \mathrm{He}$ animals died by day 5 and $50 \%$ of the $\mathrm{C} 3 \mathrm{H} / \mathrm{RV}$ mice by day 8 . Virus titers increased on day 7 in $\mathrm{C} 3 \mathrm{H} / \mathrm{RV}$ mice that were moribund. $(x)$ Moribund animals. (B) In cell cultures of resistant $\mathrm{C} 3 \mathrm{H} / \mathrm{RV}(\mathrm{O})$ primary mouse embryo fibroblasts, susceptible $\mathrm{C} 3 \mathrm{H} / \mathrm{He}(\mathbf{O})$ primary mouse embryofibroblasts, and BHK21/WI2 cells $(\mathbf{\Lambda})$. Cultures were infected with a multiplicity of infection of 10. Adapted from Brinton (1981).

bryo fibroblasts prepared from $\mathrm{C} 3 \mathrm{H} / \mathrm{RV}$ and $\mathrm{C} 3 \mathrm{H} / \mathrm{He}$ mice (Darnell and Koprowski, 1974). The rate of progeny genome RNA synthesis in resistant cells is reduced as compared to the rate in susceptible cells (Brinton, 1981). In addition, the production of a greater proportion of defective interfering virus particles by resistant cells seems to be a specific manifestation of the expression of the resistance-gene product (Brinton, 1983).

One plausible hypothesis for the observed effects of the resistancegene product is that it functions at the level of the viral replication complex. If a host protein does interact with the flavivirus replication complex affecting the recognition, binding, or copying of the template RNA by the polymerase, then an alteration in this host protein could affect the efficiency or faithfulness, or both, of viral RNA synthesis.

\section{DEFECTIVE INTERFERING PARTICLES}

The production of and the interference by defective interfering (DI) particles has been difficult to detect during acute flavivirus infections. Because virus yields are relatively low compared to other types of viruses, flaviviruses have been routinely grown in the most permissive host cells available to facilitate experimental study. Further, if a flavivirus infection induces a rapid cytopathic effect in these permissive cells, the possibility of multiple cycles of viral replication within the same host cell is eliminated. Small virus-specific RNAs (8-15 S) have often been observed in 
flavivirus-infected cells (Zebovitz et al., 1972, 1974; Takeda et al., 1978; Naeve and Trent, 1978). Wengler et al. (1978) reported that WN virus produced two low-molecular-weight RNAs $\left(6.5 \times 10^{4}\right.$ and $\left.4.2 \times 10^{4}\right)$ in BHK cells, but only the $6.5 \times 10$ dalton species in A. albopictus cells. In the same study, Uganda $S$ virus produced a $5 \times 10^{4}$ dalton RNA in both types of cells. Further, these RNAs, although of plus-strand polarity, were not capped or polyadenylated and were inactive in cell-free translation systems (Wengler et al., 1978). These results indicated that the small RNAs did not function as subgenomic mRNAs. However, the size and type of small RNAs associated with these flavivirus infections were characteristic of both the infecting virus and the host cell and apparently not the result of random degradation of $40 \mathrm{~S}$ RNA. It is not known whether or not these small intracellular RNAs are able to interfere with the replication of $40 \mathrm{~S}$ flavivirus RNA.

Rabbit kidney cells (MA-111) and Vero cells persistently infected with JE virus continue to produce low levels of infectious virus (Schmaljohn and Blair, 1977). Determination of ratios of extracellular physical particles to extracellular infectious particles indicated that defective particles were produced by these cultures. Also, particles from the persistently infected cultures interfered with the replication of wild-type JE virus. In these experiments, the degree of reduction in virus yield was proportional to the amount of virus from the persistently infected culture added. Interference with wild-type WN virus was demonstrated with virus produced by murine embryo fibroblast cultures persistently infected with WN virus (Brinton, 1982). The WN virus produced by long-term persistently infected cultures was no longer able to plaque on BHK cells. However, flaviviruslike particles of normal size were observed by electron microscopy in fluids harvested from these persistently infected cultures. The virions produced by persistently infected cells contained heterogeneous RNA that was primarily smaller than $40 \mathrm{~S}$ genome RNA. Three distinct size classes were observed when the RNA was analyzed under denaturing conditions on formaldehyde-agarose gels. RNA of each size class hybridized with ssDNA complementary to 40 S RNA, indicating that these RNAs were virus-specific and of plus-strand polarity. Although the WN virus populations produced by persistently infected cells had relatively low amounts of virions containing full-size genome RNA and a high proportion of particles containing smaller RNAs, the extent of interference with standard $\mathrm{WN}$ virus replication in BHK cells during a single grow th cycle was relatively low. A maximum reduction in the yield of infectious virus of about 1 log was consistently observed. However, the amount of $40 \mathrm{~S}$ RNA synthesized during a 1.5-hr labeling period 24 $\mathrm{hr}$ after infection in BHK cells coinfected with persistent and standard virus was reduced by $50 \%$ (Brinton, 1982). These results imply that only a portion of the virus particles in the fluids harvested from the persistently infected cultures contained RNA that could interfere substantially with wild-type $\mathrm{WN}$ virus replication in BHK cells. 
Evidence for the production of DI particles during serial undiluted passage of WN virus in murine embryo fibroblasts was reported by Darnell and Koprowski (1974). Passage of WN virus in either resistant (C3H/RV) or susceptible $(\mathrm{C} 3 \mathrm{H} / \mathrm{He})$ embryo fibroblasts resulted in a cyclic rise and fall in the extracellular virus titer characteristic of a Von Magnus effect (Von Magnus, 1954). The titer of virus produced by the $\mathrm{C} 3 \mathrm{H} / \mathrm{He}$ cells continued to cycle between $10^{4}$ and $10^{6.5} \mathrm{PFU} / \mathrm{ml}$ during 11 passages. However, passage of $\mathrm{WN}$ virus in $\mathrm{C} 3 \mathrm{H} / \mathrm{RV}$ cells resulted in the elimination of infectious virus by passage 7 (Darnell and Koprowski, 1974; Brinton, 1983). WN virus obtained after three serial undiluted passages in $\mathrm{C} 3 \mathrm{H} / \mathrm{RV}$ cells was able to interfere with standard $\mathrm{WN}$ virus replication, whereas interference was not observed with virus obtained after three passages in C3H/He cells. A. L. Smith (1981) found that Banzi virus populations obtained from the brains of $\mathrm{C} 3 \mathrm{H} / \mathrm{RV}$ mice that had been inoculated intraperitoneally contained demonstrable interfering activity. No interfering activity could be detected with virus obtained from C3H/RV animals that had been inoculated intracerebrally or with virus obtained from $\mathrm{C} 3 \mathrm{H} / \mathrm{He}$ animals inoculated by either route.

Sucrose-density-gradient analysis of WN virus E101 virus particles produced during acute infections of $\mathrm{C} 3 \mathrm{H} / \mathrm{RV}$ and $\mathrm{C} 3 \mathrm{H} / \mathrm{He}$ cells in culture indicated that the majority of the DI particles were denser than the standard virions (Fig. 7C and H) (Brinton, 1983). This could be due to the packaging of more than one deleted RNA molecule per capsid or to a slight reduction in the overall size of the DI particles compared to the standard virions. The host cell was found to influence significantly the composition of the viral progeny populations produced. WN virus replication in $\mathrm{C} 3 \mathrm{H} / \mathrm{RV}$ cells yielded progeny with a high proportion of DI particles, whereas progeny virus produced by congenic $\mathrm{C} 3 \mathrm{H} / \mathrm{He}$ cells consisted primarily of standard virions (Fig. 7D, E, I, and J). The ratio of DI particles to standard virions could be shifted by passaging virus from one cell type to the other (Fig. 8). WN virus pools were prepared in resistant $\mathrm{C} 3 \mathrm{H} / \mathrm{RV}$ or susceptible $\mathrm{C} 3 \mathrm{H} / \mathrm{He}$ cells by infecting cells with a multiplicity of infection of 10 , harvesting the culture fluid $48 \mathrm{hr}$ after infection, and then concentrating the virus 10 -fold. These virus pools were used to infect either $\mathrm{C} 3 \mathrm{H} / \mathrm{He}$ or $\mathrm{C} 3 \mathrm{H} / \mathrm{RV}$ cell cultures, and the RNA present in progeny particles produced during the first and second cycles of replication was analyzed on $10-30 \%$ SDS sucrose gradients (Fig. 8). The C3H/ He cells were able to preferentially amplify virus with full-size RNA, while $\mathrm{C} 3 \mathrm{H} / \mathrm{RV}$ cultures selectively amplified the particles containing the small-size RNAs. Homologous interference could be demonstrated with $\mathrm{WN}$ virus produced by $\mathrm{C} 3 \mathrm{H} / \mathrm{RV}$ cells, but not with virus produced by $\mathrm{C} 3 \mathrm{H} / \mathrm{He}$ cells. Four size classes of small RNAs with sedimentation coefficients of approximately $8,15,26$, and $34 \mathrm{~S}$ were consistently observed to be associated with extracellular particles. The four species of small RNAs were presumed to have been present in the stock of WN virus E101 used in these experiments. Cloning of the virus stock by six consecutive 

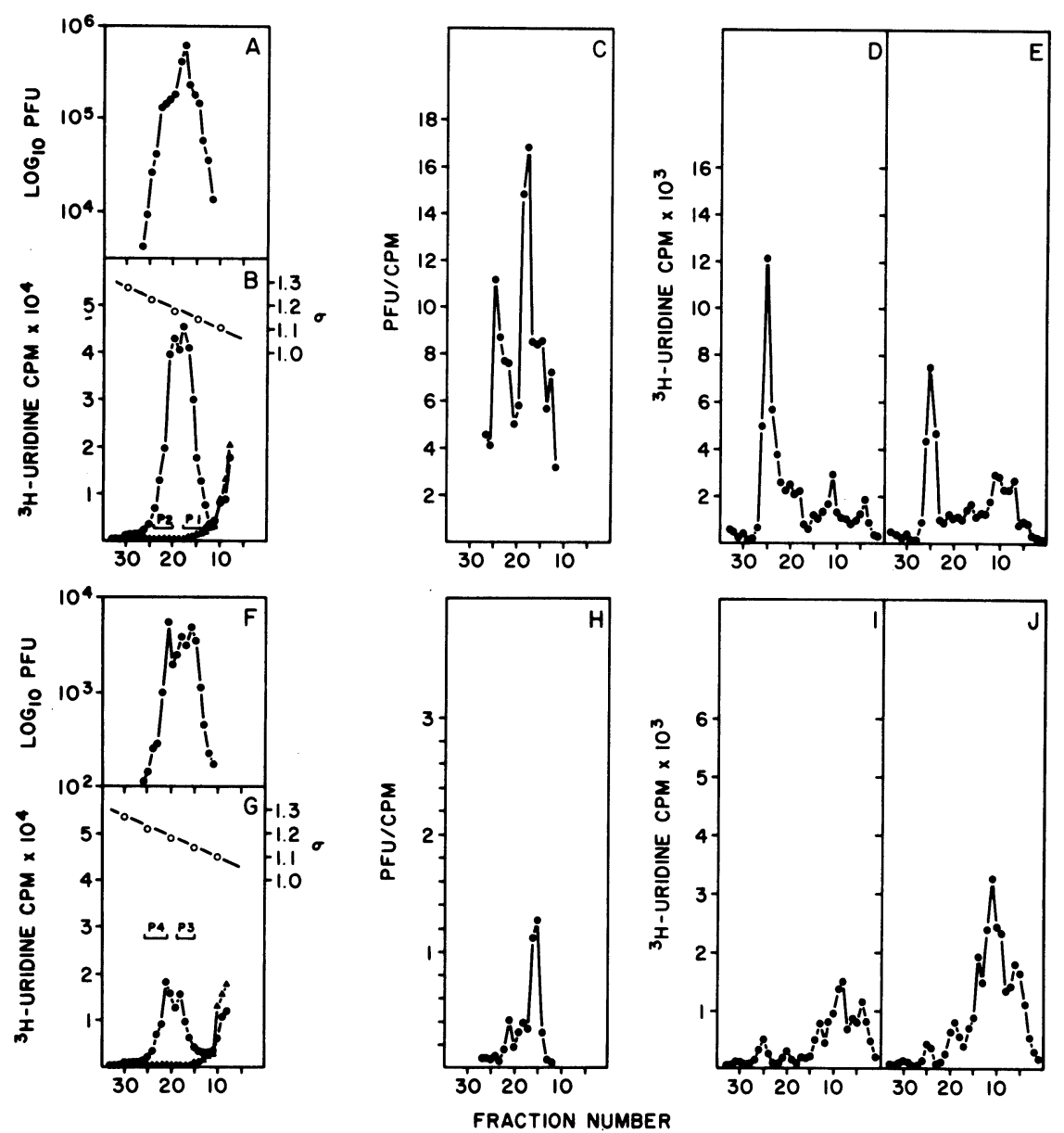

FIGURE 7. Isopycnic density-gradient centrifugation of WN progeny virus produced by susceptible $\mathrm{C} 3 \mathrm{H} / \mathrm{He}$ and resistant $\mathrm{C} 3 \mathrm{H} / \mathrm{RV}$ embryofibroblasts. Cultures were labeled with $\left[{ }^{3} \mathrm{H}\right]$ uridine at 6-32 hr after infection with WN virus at a multiplicity of infection of 10 . The infectivity of the infecting virus was determined by plaque assay in BHK cells. Harvested culture fluids were clarified and centrifuged directly on $15-45 \%$ isopycnic sucrose density gradients. (A-E) Virus produced by $\mathrm{C} 3 \mathrm{H} / \mathrm{He}$ cells; ( $\mathrm{F}-\mathrm{J}$ ) virus produced by $\mathrm{C} 3 \mathrm{H} / \mathrm{RV}$ cells. Samples of each gradient fraction were analyzed for acid-insoluble radioactivity $(B, G)$ and infectivity $(\mathrm{A}, \mathrm{F})$. The ratio of infectivity to uridine counts was calculated for each gradient fraction $(\mathrm{C}, \mathrm{H})$. Fractions were pooled as indicated, and the extracted RNA was sedimented on $15-30 \%$ SDS-sucrose gradients (D, E, I, and J for pools $1-4$, respectively). (-) Virusinfected culture fluid; $(\mathbf{\Lambda})$ uninfected control culture fluid; $(O) \sigma$ values. The direction of sedimentation is from right to left. From Brinton (1983).

plaque-purification steps reduced the amount of DI particles present, but did not completely eliminate them. Stocks of other flaviviruses might be expected to differ in the size classes of the DI particle RNAs they contain. Whether the RNAs in each of the four size classes are able to interfere with the replication of wild-type WN virus is not currently 


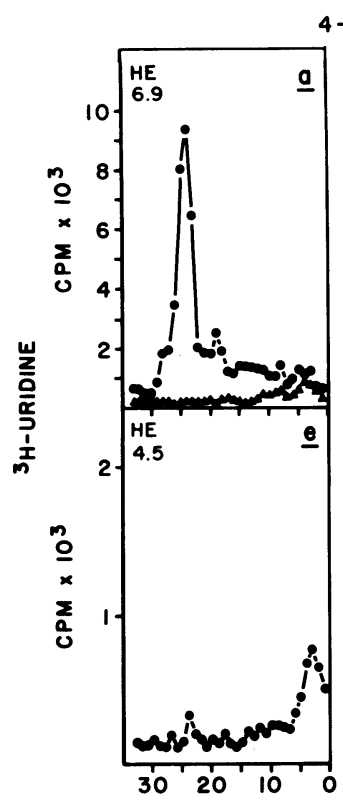

4-28 hrs

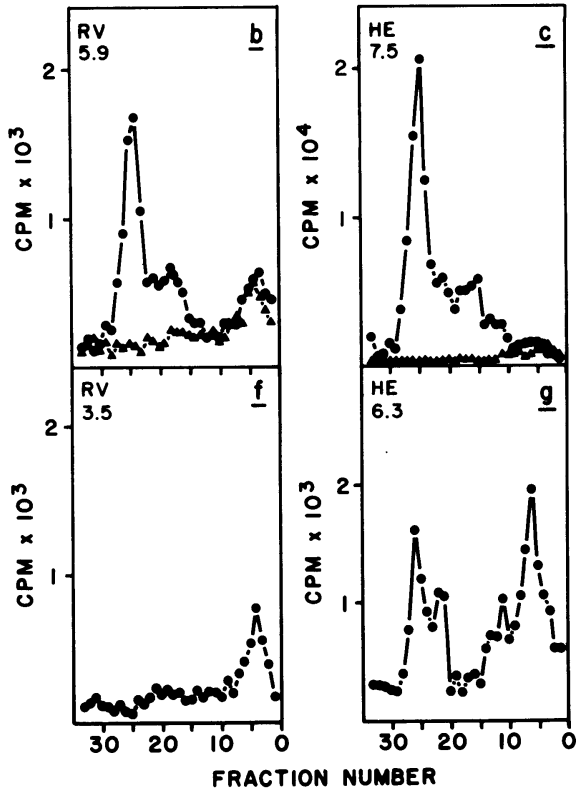

28-52 hrs

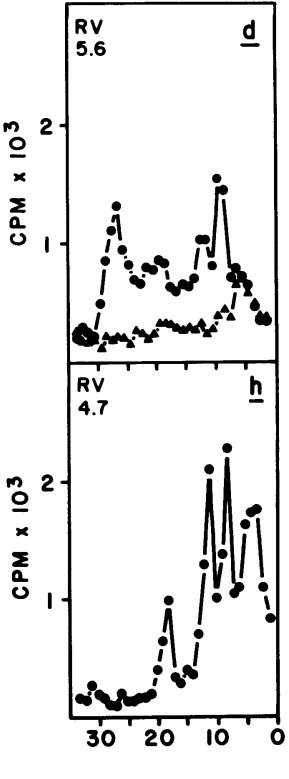

FIGURE 8. Sucrose-gradient sedimentation of extracellular progeny virion RNA produced by resistant $\mathrm{C} 3 \mathrm{H} / \mathrm{RV}$ or susceptible $\mathrm{C} 3 \mathrm{H} / \mathrm{He}$ cells infected with pools of $\mathrm{WN}$ virus that had been grown in one of the two cell types for $48 \mathrm{hr}$ (see Fig. 7) and concentrated 10-fold. Cultures were incubated with $\left[{ }^{3} \mathrm{H}\right]$ uridine, and virus was harvested at 28 or $52 \mathrm{hr}$ after infection. The RNA was extracted and sedimented on $15-30 \%$ SDS-sucrose gradients. (ad) Virus produced by cells infected with $\mathrm{C} 3 \mathrm{H} / \mathrm{He}-\mathrm{WN}$ virus $(\mathrm{MOI}=1)$; $(\mathrm{e}-\mathrm{h})$ virus produced by cells infected with $\mathrm{C} 3 \mathrm{H} / \mathrm{RV}-\mathrm{WN}$ virus $(\mathrm{MOI}=0.1)$. The host cell is indicated in the upper left-hand corner of each panel, as is the total infectivity $\left(\log _{10}\right)$ of the harvested progeny virus. (@) Infected; $(\mathbf{\Delta})$ uninfected control. The direction of sedimentation is from right to left. From Brinton (1983).

known. However, the two smallest species of RNA appeared to be present in the greatest relative abundance in the progeny virus produced by $\mathrm{C} 3 \mathrm{H} /$ $\mathrm{RV}$ cells, and these virus populations demonstrated the highest interfering activity. It is tempting to speculate that the host proteins specified by the alleles of the murine flavivirus resistance gene may interact specifically at the level of viral RNA synthesis, affecting template-polymerase interactions. If a host protein does interact with the flavivirus replication complex and, further, if the $\mathrm{C} 3 \mathrm{H} / \mathrm{He}$ and $\mathrm{C} 3 \mathrm{H} / \mathrm{RV}$ cells do contain different alleles for this protein, then an interaction between the viral polymerase and these host proteins could influence the enrichment of or extent of interference by flavivirus DI particles. Data from both negative-strand RNA (Lazzarini et al., 1981; Schubert et al., 1979) and other positive-strand RNA (Baron and Baltimore, 1982; Dasgupta et al., 1980) virus systems indicate that host proteins can be involved specifically in viral RNA synthesis. It has also been suggested that interactions between viral polymerases and host factors could explain the apparent 
role of the host cell in DI-particle generation (Holland et al., 1976; Kang and Allen, 1978; Lazzarini et al., 1981; Schubert et al., 1979).

\section{PERSISTENT INFECTIONS}

Persistence of flaviviruses in experimental animals has been reported. Webster and Clow (1936) observed that genetically resistant BRVR mice inoculated intranasally with SLE virus developed a subclinical encephalitis that was histologically apparent for 3 months after infection. Virus could be isolated from the brains of these mice for about 1 month after infection. Slavin (1943) reported the persistence of SLE in the brains of mice for over 5 months after infection. Transplacental transmission of JE virus was demonstrated in intraperitoneally infected females during consecutive pregnancies occurring as long as 6 months after infection (Mathur et al., 1982).

Persistence of various tick-borne flaviviruses has been observed more often. Kyasanur Forest virus normally kills mice after inoculation, but occasionally paralyzed infected mice survive for many months (Virus Research Center, Poona, 1963; Price, 1966). When the animals were sacrificed, virus was isolated from the brains and other tissues of these paralyzed mice. Serum neutralizing antibody could often not be detected, even though the paralyzed mice were resistant to subsequent virus challenge. Persistence of louping ill virus in immunosuppressed guinea pigs for more than 50 days after infection was reported by Zlotnik et al. (1976). Chronic encephalitis induced in monkeys by TBE virus (Russian springsummer virus) has been reported by a number of investigators (Ilienko et al., 1974; Zlotnik et al., 1976; Andzhaparidze et al., 1978; Asher, 1979; Malenko et al., 1982; Fokina et al., 1982; Frolova and Pogodina, 1984). Chronic histopathological lesions and infectious virus were detected as late as 789 days after infection. Some indication that flaviviruses may also persist for long periods in humans has been obtained (Edelman et al., 1976; Monath, 1971; Ogawa et al., 1973).

Establishment of persistent infections has been successfully accomplished with a number of different flaviviruses in a variety of mammalian, arthropod, and reptilian cell lines. In some instances, due to the intense cytopathic effect of the particular flavivirus on the host-cell line, persistent infections could be established only when techniques were used to reduce the extent of the virus-induced cell damage. Schmaliohn and Blair (1977) established persistent infections in a line of rabbit kidney cells (MA-111) with JE virus that had previously been subjected to 3040 serial undiluted passages in MA-111 cells. Infection of some host-cell lines with a particular flavivirus does not result in extensive destruction of the cells. Under these circumstances, it is possible to establish persistent infections simply by routine subculturing of surviving infected cells. This was the case in the establishment of persistent infections with 
dengue viruses in either HeLa cells (Maguire and Miles, 1965), rhesus monkey testis cells (Hotta and Evans, 1956), green monkey kidney cells (Shimazu et al., 1966), or an A. albopictus cell line (Sinarachatanant and Olson, 1973), a line of Toxorhynchites amboinensis cells (Kuno, 1982) or human KB cells (Beasley et al., 1960; Schulze and Schlesinger, 1963); WN virus in either murine L-929 cells (Jarman et al., 1968), lines of murine embryo fibroblasts (Brinton, 1982), or monkey LLC-MK 2 cells (Katz and Goldblum, 1968); and SLE virus in a turtle heart (TH-1) cell line (Mathews and Vorndam, 1982).

Interferon production, although sometimes demonstrable in persistently infected mammalian-cell cultures, does not appear to be directly involved in the maintenance of flavivirus persistence (Schmaljohn and Blair, 1977; Katz and Goldblum, 1968; Brinton, 1982). DI virus particles were produced by rabbit kidney cells (MA-11) persistently infected with JE virus (Schmaljohn and Blair, 1977) and by murine embryo fibroblast cell lines persistently infected with WN virus (Brinton, 1982). DI virus particles may well play an important role in the establishment and maintenance of flavivirus persistent infections.

Virus produced by persistently infected cultures often progressively changes from the parental virus phenotype. SLE virus from persistently infected turtle heart cells 1 year after infection was less virulent for mice, had an altered cell-culture host range, and had an increased thermal liability as compared to the virus used to initiate the infection (Mathews and Vorndam, 1982). Dengue viruses of all four serotypes obtained 1 year after infection from separate persistently infected nonvector mosquito $T$. amboinensis cultures showed changes in antigenic reactivity, increased temperature sensitivity, and decreased neurovirulence in mice as compared to the original viruses used to initiate the infections (Kuno, 1982). WN virus obtained from persistently infected murine embryo fibroblasts had lost its ability to plaque in BHK-21 cells. Also, temperature-sensitive mutants and a replication-efficient mutant of WN virus were isolated from these persistently infected cell-culture fluids (Brinton, 1981, 1982; Brinton et al., 1985). Analysis of the WN virus progeny populations obtained from persistently infected cultures indicated that these cultures simultaneously replicated several different mutant virus populations.

In some long-term persistently infected cultures, the low levels of infectious virus are produced by only a small proportion of the cells in the culture. Only 4 of 200 cells cloned from rabbit-cell cultures persistently infected with JE virus contained immunofluorescence-detectable viral antigen and released infectious virus (Schmaljohn and Blair, 1979). Sucrose-gradient analysis of $\left[{ }^{3} \mathrm{H}\right]$ uridine-labeled cell extracts indicated that all the clones produced some intracellular actinomycin-D-resistant RNA. However, culture supernatants were not analyzed for the presence of released virus, which was unable to induce plaques in test-cell monolayers. Superinfection of nonproducer cell clones with JE virus led to the production of infectious virus in the absence of any cytopathic effect 
(Schmaljohn and Blair, 1979). JE virus infection normally produces extensive cytopathology in rabbit-cell cultures.

Virus-specific immunofluorescence was observed in $100 \%$ of cells in murine-cell cultures persistently infected with WN virus (Brinton, 1982). Some cells $(20-70 \%)$ showed a bright perinuclear and/or diffuse cytoplasmic fluorescence during the first 15 weekly subcultures. Other cells in the initial subcultures and all cells in long-term persistently infected cultures showed fainter perinuclear and/or focal cytoplasmic viral-specific fluorescence. All the WN-virus-persistently infected cultures continued to release virus particles throughout 2.5 years of cultivation. However, the virus produced by long-term cultures maintained at $37^{\circ} \mathrm{C}$ could no longer plaque on $\mathrm{BHK}$ cells and contained predominantly heterogenous subgenomic viral RNAs (Brinton, 1982). In contrast to what was observed with JE-virus-persistently infected cultures, superinfection of long-term $\mathrm{WN}$-virus-persistently infected cultures with parental virus did not result in the release of progeny virus with the ability to cause plaques. However, superinfection with a replication-efficient mutant (RE-WN virus) did (Brinton and Fernandez, 1983).

The results obtained with persistent flavivirus infections indicate that if a flavivirus causes extensive cytopathology in a particular host cell, a persistent infection can be established only when some method of reducing the viral cytopathic effect is employed during the initial subcultures of the infected cells. Once established, persistently infected cultures produce progeny virus that becomes progressively less cytopathic. Many types of mutant viruses are generated and simultaneously replicated, including deletion mutants with homologous interfering activity and temperature-sensitive mutants.

\section{FLAVIVIRUS MUTANTS}

A reduction in viral virulence has been observed during serial passage of many of the flaviviruses in cell culture and eggs. Mixed populations of large- and small-plaque variants are commonly observed in passaged virus stocks as well as in field isolates obtained from humans, insects, rodents, and birds (Hammon et al., 1963; Mayer, 1963; Paul, 1966; Price et al., 1963; Theiler, 1951; Eckels et al., 1976). Analysis of selected plaques obtained from such virus populations has shown that in general, plaque size, virulence, and temperature sensitivity are only rarely correlated; however, exceptions have been observed. A small-plaque variant of Central European TBE virus obtained from a persistently infected human amnion-cell culture had reduced virulence for mice (Mayer, 1963). A Kyasanur Forest virus small-plaque mutant obtained after passage in monkey kidney-epithelial-cell cultures was both reduced in virulence and temperature-sensitive (Paul, 1966). A small-plaque mutant of dengue 2 virus, which was isolated after a single passage of a human serum in 
primary green monkey kidney cells, was temperature-sensitive and showed reduced virulence (Eckels et al., 1976). Persistently infected $A$. albopictus cells yielded a small-plaque dengue 2 virus mutant that was temperature-sensitive as well as of reduced virulence (Igarashi, 1979).

Spontaneously arising temperature-sensitive mutants of both JE virus (Halle and Zebovitz, 1977) and dengue 2 virus (Eckels et al., 1976) have been tested for use as attenuated live virus vaccines. Undiluted passage of the S-1 dengue virus mutant sometimes yielded large-plaque variants that were virulent and not temperature-sensitive (Eckels et al., 1980). Attempts to define the lesions of spontaneous flavivirus temperaturesensitive mutants have rarely been reported. The S-1 temperature-sensitive clone of dengue 2 virus isolated by Eckels et al. (1976) was more thermolabile at the nonpermissive temperature of $38.5^{\circ} \mathrm{C}$ than the parental virus. Viral adsorption studies indicated that the temperature-sensitive protein produced by this mutant was probably a structural protein involved in virus attachment to cells (Eckels et al., 1983).

Flavivirus temperature-sensitive mutants have been isolated after chemical mutagenesis (Table III). Tarr and Lubiniecki (1976) found 7 temperature-sensitive clones of dengue 2 virus among 138 clones isolated from virus grown in primary hamster kidney cells in the presence of 5azacytidine. Of these dengue mutants, 5 were partially characterized; 3 were RNA-plus mutants, while 2 were RNA-minus mutants. Complementation analysis indicated that these mutants represented four complementation groups. Virus yields in these experiments were assayed by microquantitative complement fixation.

Recently, temperature-sensitive mutants of JE virus (Eastman and Blair, 1985) and SLE virus (Hollingshead et al., 1983) have been efficiently induced by chemical mutagenesis of infected cells also treated with actinomycin D. Both 5-fluorouracil and 5-azacytidine were used to induce SLE mutants. Flavivirus infection does not significantly affect host-cell metabolism, and treatment of host cells with actinomycin D apparently enhances the incorporation of the mutagens into the flavivirus RNA. Nine temperature-sensitive mutants of SLE were obtained; two were RNA-minus, while the remaining seven were RNA-plus mutants. Complementation analysis indicated that these mutants represented four complementation groups, with two of these groups containing more than one of the mutants. Ten mutants of JEV were isolated: five were RNAplus mutants and five were RNA-minus mutants. Seven complementation groups were defined with these ten mutants. Three of the complementation groups contained RNA-minus mutants. At the nonpermissive temperature, mutants in the three RNA minus complementation groups produced no detectable protein, with the exception of one mutant which produced low levels of protein. The RNA plus mutants produced normal amounts of protein at the non-permissive temperature, again with one exception which produced a low amount of protein. The complementation observed between JEV mutants was sometimes nonreciprocal and 


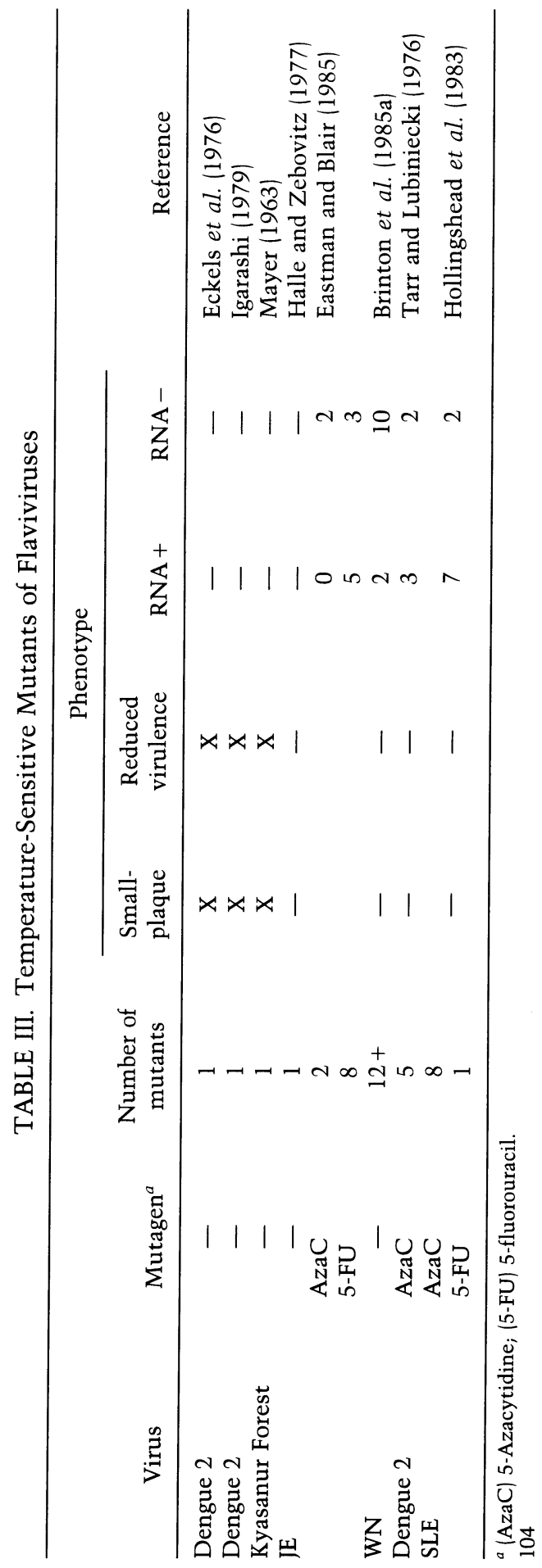


interference between certain pairs of mutants was also observed (Eastman and Blair, 1985).

Temperature-sensitive mutants of WN virus were generated by longterm persistently infected cultures of genetically resistant $\mathrm{C} 3 \mathrm{H} / \mathrm{RV}$ and susceptible $\mathrm{C} 3 \mathrm{H} / \mathrm{He}$ murine embryo fibroblasts maintained at $32^{\circ} \mathrm{C}$ (Brinton et al., 1985). The WN virus used to initiate these infections contained no detectable temperature-sensitive virus. The $40 / 32^{\circ} \mathrm{C}$ plaquing ratio of progeny virus obtained from persistently infected cultures maintained at $37^{\circ} \mathrm{C}$ decreased only slightly during $10-15$ subcultures. Thereafter, although these cultures continued to produce $\mathrm{WN}$ virus particles, they no longer produced $\mathrm{WN}$ virus able to cause plaques on BHK cells. Progeny virus from duplicate cultures shifted to $32^{\circ} \mathrm{C}$ at subculture 6 was also tested periodically for its ability to plaque at 40 and at $32^{\circ} \mathrm{C}$. Viral progeny titers increased after the shift to $32^{\circ} \mathrm{C}$, indicating the possible presence of temperature-sensitive mutants. Temperature-sensitive mutants were subsequently isolated from culture fluids obtained from both persistently infected resistant and susceptible cells. However, only in the resistant cell cultures did temperature-sensitive virus become the majority population (Table IV). The resistant cells appear to provide an environment that is advantageous for the amplification of flavivirus temperature-sensitive mutants. It has been previously demonstrated that resistant $\mathrm{C} 3 \mathrm{H} / \mathrm{RV}$ cells preferentially amplify $\mathrm{WN}$ virus defective RNAs (Brinton, 1983). The growth of wild-type virus is reduced in the resistant cells, and this may allow temperature-sensitive mutants to compete more effectively during persistent infections in resistant cells. Preliminary data indicate that temperature-sensitive mutants generated by the resistant cultures are in general less leaky than those obtained from the susceptible cultures. To date, no complementation among the $\mathrm{WN}$ virus temperaturesensitive mutants has been demonstrable. The majority of mutants obtained from the $\mathrm{C} 3 \mathrm{H} / \mathrm{RV}$ cultures have an RNA-minus phenotype. It is possible that the $\mathrm{C} 3 \mathrm{H} / \mathrm{He}$ and $\mathrm{C} 3 \mathrm{H} / \mathrm{RV}$ cultures selectively amplify different groups of temperature-sensitive mutants (Brinton et al., 1985).

In addition to the temperature-sensitive mutants, a non-temperaturesensitive mutant of $\mathrm{WN}$ virus was isolated from the culture fluid of one of the genetically resistant persistently infected $\mathrm{C} 3 \mathrm{H} / \mathrm{RV}$ cultures. This mutant produced higher yields of virus and incorporated $\left[{ }^{3} \mathrm{H}\right]$ uridine into intracellular 40 S RNA more efficiently than the parental virus and grew equally well in resistant and susceptible cell cultures (Brinton, 1981). Analysis of the genome RNA of this replication-efficient mutant, designated RE-WN virus, by oligonucleotide fingerprinting indicated that the mutant RNA differed from the genome RNA of the parent by three unique oligonucleotides. The RE-WN virus was insensitive to interference by a parental WN virus pool enriched in DI particles even during replication in resistant $\mathrm{C} 3 \mathrm{H} / \mathrm{RV}$ cells (Brinton and Fernandez, 1983). This mutant was also able to superinfect persistently infected murine cell cultures, whereas the parental virus was not. 
TABLE IV. Temperature Sensitivity of Plaques Picked from Persistently Infected RV and He Culture Fluids

\begin{tabular}{ccc}
\hline \multicolumn{1}{c}{ Culture } & Passage & $\begin{array}{c}\text { Number of } t \text { mutants/ } \\
\text { number of plaques picked }\end{array}$ \\
\hline Susceptible cell lines & & \\
He 100 & 9 & $2 / 24$ \\
& 11 & $1 / 10$ \\
& 18 & $0 / 20$ \\
& 33 & $0 / 21$ \\
He 103 & 37 & $1 / 13$ \\
& 53 & $0 / 8$ \\
& 57 & $1 / 10$ \\
Resistant cell lines & 8 & $0 / 24$ \\
RV 100 & 11 & $3 / 12$ \\
& 17 & $0 / 12$ \\
& 18 & $2 / 22$ \\
& 23 & $1 / 27$ \\
& 10 & $0 / 40$ \\
RV 103 & 12 & $0 / 12$ \\
& 14 & $1 / 8$ \\
& 17 & $1 / 17$ \\
& 21 & $47 / 70$ \\
& 24 & $20 / 20$ \\
& 13 & $0 / 16$ \\
& 18 & $0 / 14$ \\
& 25 & $1 / 10$ \\
& 27 & $5 / 20$ \\
& 31 & $19 / 23$ \\
& 43 & $3 / 7$ \\
& 57 & $5 / 6$ \\
& & \\
& & \\
& &
\end{tabular}

${ }^{a}$ Medium from persistently infected cultures was collected at the time of each of the weekly subcultures. Plaques were picked from $32^{\circ} \mathrm{C}$ titration plates about every 2-4 passages. Virus contained in the picked plaques was then titrated by plaque assay at both 32 and $40^{\circ} \mathrm{C}$. Plaque isolates displaying a $40 / 32^{\circ} \mathrm{C}$ ratio of 0.01 or less were scored as temperature-sensitive.

Comparison of the $3^{\prime}$-terminal 135 nucleotides of the parental WN virus and the RE-WN virus showed no differences between the two RNAs in this noncoding region of the genome presumed to contain sequences involved in the recognition and binding of the replication complex (Brinton et al., 1986). Future studies will focus on the 3 ' noncoding region of the minus-strand RNA and the viral polymerase gene sequences. This mutant provides a unique tool for further study of the factors involved in regulating flavivirus RNA synthesis.

\section{SUMMARY}

During the past five years, much has been learned about flavivirus infections and replication strategy. By 1984, a sufficient amount of new 
information had been obtained to institute the reclassification of flaviviruses (Westaway et al., 1986). The most significant recent advance has been provided by the nucleotide sequence of the YF virus genome and the partial map of the viral genes determined by Rice et al. (1985) (see Chapter 10). The new sequence data have confirmed the prediction from in vitro translation data that the viral structural genes are located at the $5^{\prime}$ end of the coding region. The mapping of the flavivirus genes on the nucleotide sequence has provided a precise delineation of the number and sizes of the flavivirus nonstructural proteins and of the made of flavivirus protein translation and processing.

Nine epitopes of the virion glycoprotein have been mapped for three different flaviviruses (Roehrig et al., 1983; J. J. Schlesinger et al., 1983; Heinz et al., 1983) with panels of monoclonal antibodies. Future comparisons of antigenic variants at the level of the glycoprotein nucleotide sequence should greatly enhance our understanding of the complex antigenic relationships known to exist among flaviviruses, the determinants of virulence, and the various biological functions of the E protein such as hemagglutination, attachment, and fusion.

The existence of a very stable stem and loop structure composed of the first 84-87 bases at the 3' terminus of the flavivirus genome has been established (Brinton et al., 1986; Rice et al., 1985). Such a structure could function in polymerase recognition and binding and/or capsid protein binding. Many of the plus-stranded plant viruses also have no poly(A) instead have a transfer-RNA-like structure at their $3^{\prime}$ termini (E. R. Strauss and J. H. Strauss, 1983). Future comparison of 5' - and $3^{\prime}$-terminal sequences from a variety of flaviviruses should indicate highly conserved regions that may be important signals for replicase and transcriptase recognition and binding. Comparisons between YF virus and WN virus indicate that a high level of sequence conservation is observed in the first two nucleotides at the 3 ' termini of both plus and minus strands, a heptanucleotide located near each terminus, and a 27-base sequence beginning at nucleotides 85 or 87 from the $3^{\prime}$ termini of the genome RNA (Brinton et al., 1986; Rice et al., 1985).

The generation of flavivirus DI particles has been demonstrated during acute infections with WN virus (Brinton, 1983) and persistent infections with JE virus (Schmaljohn and Blair, 1977) and WN virus (Brinton, 1982). However, the mechanism of generation of the various size classes of deleted viral RNAs observed is not yet known. Also, the molecular basis for the differential ability of various cell cultures to generate and/ or amplify these deleted flavivirus RNAs is not understood. Sequence analysis of flavivirus DI RNAs should yield further information about the sequences and secondary structure elements required for transcription and replication of flavivirus RNAs.

The fact that many flaviviruses can replicate in a wide range of vertebrate hosts and in arthropod vectors implies that any functions required from the host cell during the flavivirus replication cycle must be present 
in a wide range of host species. The existence of the murine flavivirusspecific resistance gene indicates that one of these host proteins can differ in the efficiency with which it can interact with flavivirus macromolecules. Such host factors could affect both the efficiency and the fidelity of flavivirus RNA transcription.

Many questions concerning flavivirus replication remain unanswered. For instance, the functions of the various nonstructural proteins have not been delineated. The mechanism by which flavivirus genome RNAs are capped at their $5^{\prime}$ end is not known. Does a host-cell enzyme or a viral enzyme cap the RNA? The mechanism by which plus-strand RNA is made efficiently, while minus-strand RNA is not, is also not understood. The proteolytic enzymes involved in the processing of the flavivirus proteins from precursors have not been identified. Continued study of flaviviruses on a molecular level during the coming years should greatly increase our knowledge of flavivirus replication.

\section{REFERENCES}

Ahlquist, P., Strauss, E. G., Rice, C. M., Strauss, J. H., Haseloff, J., and Zimmern, D., 1985, Sindbis virus proteins ns $\mathrm{P} 1$ and ns $\mathrm{P} 2$ contain homology to nonstructural proteins from several RNA plant viruses, I. Virol. 53:536.

Andzhaparidze, O. G., Rozina, E. E., Bogomolova, N. N., and Boriskin, Yu. S., 1978, Morphological characteristics of the infection of animals with tick-borne encephalitis virus persisting for a long time in cell cultures, Acta Virol. 22:218.

Asher, D. M., 1979, Persistent tick-borne encephalitis infection in man and monkeys: Relation to chronic neurologic disease, in: Artic and Tropical Arboviruses: Proceedings of the 2nd International Symposium on Artic Arboviruses, Mont Gabriel, Canada, pp. 179-195, Academic Press, New York.

Baron, M. H., and Baltimore, D., 1982, Purification and properties of a host cell protein required for poliovirus RNA replication in vitro, J. Biol. Chem. 257:12,351.

Beasley, A. R., Lichter, W., and Sigel, M. M., 1960, Studies on latent infections of tissue cultures with dengue virus. Arch. Virusforsch. 10:672.

Bell, J. R., Kinney, R. M., Trent, D. W., Lenches, E. M., Dalgarno, L., and Strauss, J. H., 1985, Amino-terminal amino acid sequences of structural proteins of three flaviviruses, Virology 143:224.

Boulton, R. W., and Westaway, E. G., 1976, Replication of the flavivirus Kunjin: Proteins, glycoproteins and maturation associated with cell membranes, Virology 69:416.

Brandriss, M. W., and Schlesinger, J. J., 1984, Antibody-mediated infection of P388D1 cells with 17D yellow fever virus: Effects of chloroquine and cytochalasin B, J. Gen. Virol. 65:791.

Brandt, W. E., McCown, J. M., Top, F. H., Jr., Bancroft, W. H., and Russell, P. K., 1979, Effect of passage history on dengue-2 virus replication in subpopulations of human leukocyte, Infect. Immun. 26:534.

Brandt, W. E., McCown, J. M., Gentry, M. K., and Russell, P. K., 1982, Infection enhancement of dengue type 2 virus in the U-937 human monocyte cell line by antibodies to flavivirus cross-reactive determinants, Infect. Immun. 36:1036.

Brawner, T. A., Trousdale, M. O., and Trent, D. W., 1979, Cellular localization of Saint Louis encephalitis virus RNA replication, Acta Virol. 23:284.

Brinton, M. A., 1981, Isolation of a replication-efficient mutant of West Nile virus from a persistently infected genetically resistant mouse cell culture, I. Virol. 39:413. 
Brinton, M. A., 1982, Characterization of West Nile virus persistent infections in genetically resistant and susceptible mouse cells. I. Generation of defective nonplaquing virus particles, Virology 116:84.

Brinton, M. A., 1983, Analysis of extracellular West Nile virus particles produced by cell cultures from genetically resistant and susceptible mice indicates enhanced amplification of defective interfering particles by resistant cultures, J. Virol. 46:860.

Brinton, M. A., and Fernandez, A. V., 1983, A replication-efficient mutant of West Nile virus is insensitive to DI particle interference, Virology 129:107.

Brinton, M. A., and Nathanson, N., 1981, Genetic determinants of virus susceptibility: Epidemiologic implications of murine models, Epidemiol. Rev. 3:115.

Brinton, M. A., Arnheiter, H., and Haller, O., 1982, Interferon independence of genetically controlled resistance to flaviviruses, Infect. Immun. 36:284.

Brinton, M. A., Blank, K. J., and Nathanson, N., 1984, Host genes that influence susceptibility to viral diseases, in: Concepts in Viral Pathogenesis (A. L. Notkins and M. B. A. Oldstone, eds.), pp. 71-78, Springer-Verlag, New York.

Brinton, M. A., Davis, J., and Schaefer, D., 1985, Characterization of West Nile virus persistent infections in genetically resistant and susceptible mouse cells. II. Generation of temperature-sensitive mutants, Virology 140:152.

Brinton, M. A., Fernandez, A. V., and Amato, J., 1986, The 3'-nucleotides of flavivirus genomic RNA form a conserved secondary structure, Virology, submitted.

Calberg-Bacq, C.-M., Rentier-Delrue, F., Osterrieth, P. M., and Duchesne, P. Y., 1975, Electron microscopy studies on Banzi virus particle and its development in the suckling mouse brain, J. Ultrastruct Res. 53:193.

Caliguiri, L. A., and Tamm, I., 1970, The role of cytoplasmic membranes in poliovirus biosynthesis, Virology 42:100.

Calisher, C. H., Dalrymple, J. N., Karabatsos, N., Shope, R. E., Bishop, D. H. L., Brandt, W., Casals, J., Porterfield, J. S., Tesh, R. B., and Westaway, E. G., 1986, Antigenic relationships among flaviviruses as determined by cross neutralization: Proposed antigenic classification, submitted.

Cammack, N., and Gould, E. A., 1985, Conditions for haemolysis by flaviviruses and characterization of the haemolysin, J. Gen. Virol. 66:2291.

Cardiff, R. D., Dalrymple, J. M., and Russell, P. K., 1973, RNA polymerase in group B arbovirus (dengue-2) infected cells, Arch. Gesamte Virusforsch. 40:392.

Cardosa, M. J., Porterfield, J. S., and Gordon, S., 1983, Complement receptor mediates enhanced flavivirus replication in macrophages, J. Exp. Med. 158:258.

Chamberlain, R. W., 1980, Epidemiology of arthropod-borne togaviruses: The role of arthropods as hosts and vectors and of vertebrate hosts in natural transmission cycles, in: The Togaviruses (R. W. Schlesinger, ed.), pp. 175-227, Academic Press, New York.

Chu, P. W. G., and Westaway, E. G., 1985, Replication strategy of Kunjin virus: Evidence for recycling role of replicative form RNA as template in semiconservative and asymmetric replication, Virology 140:68.

Cleaves, G. R., and Dubin, D. T., 1979, Methylation status of intracellular dengue type 2 40S RNA, Virology 96:159.

Cleaves, G. R., and Schlesinger, R. W., 1977, Characterization of polysomal RNA's from dengue virus infected KB cells, Abstr. Am. Soc. Microbiol. S-50:287.

Cleaves, G. R., Ryan, T. E., and Schlesinger, R. W., 1981, Identification and characterization of type 2 dengue virus replicative intermediate and replicative form RNAs, Virology 111:73.

Dalton, S., 1972, Infection of neuronal and glial tissue in vivo by Langat, a group B arbovirus, Ann. Inst. Pasteur (Paris) 123:489.

Darnell, M. B., and Koprowski, H., 1974, Genetically determined resistance to infection with group $B$ arboviruses. II. Increased production of interfering particles in cell cultures from resistant mice, I. Infect. Dis. 129:248.

Darnell, M. B., Koprowski, H., and Lagerspetz, K., 1974, Genetically determined resistance to infection with group B arboviruses. I. Distribution of the resistance gene among 
various mouse populations and characteristics of gene expression in vivo, J. Infect. Dis. 129:240.

Dasgupta, A., Zabel, P., and Baltimore, D., 1980, Dependence of the activity of the poliovirus replicase on a host cell protein, Cell 19:423.

Daughaday, C. C., Brandt, W. E., McCown, J. M., and Russell, P. K., 1981, Evidence for two mechanisms of dengue virus infection of adherent human monocytes: Trypsin-sensitive virus receptors and trypsin-resistant immune complex receptors, Infect. Immun. 32:469.

Demsey, A., Steere, R. L., Brandt, W. E., and Veltri, B. J., 1974, Morphology and development of dengue-2 virus employing the freeze-fracture and thin-section techniques, J. Ultruct. Res. 46:103.

Deubel, V., Crouset, J., Benichou, D., Digoutte, J.-P., Bouloy, M., and Girard, M., 1983, Preliminary characterization of the ribonucleic acid of yellow fever virus, Ann. Virol. 134E:581.

Eastman, P. S., and Blair, C. D., 1985, Temperature-sensitive mutants of Japanese encephalitis virus, J. Virol. 55:611.

Eckels, K. H., Brandt, W. E., Harrison, V. R., McCown, J. M., and Russell, P. K., 1976, Isolation of a temperature-sensitive dengue- 2 virus under conditions suitable for vaccine development, Infect. Immun. 14:1221.

Eckels, K. H., Harrison, V. R., Summers, P. L., and Russell, P. K., 1980, Dengue-2 vaccine: Preparation from a small plaque virus clone, Infect. Immun. 27:175.

Eckels, K. H., Summers, P. L., and Russell, P. K., 1983, Temperature-sensitive events during the replication of the attenuated S-1 clone of dengue type 2 virus, Infect. Immun. 39:750.

Edelman, R., Schneider, R. J., Vejiajiva, A., Pornpibul, R., and Voodhikul, P., 1976, Persistence of virus-specific IgM and clinical recovery after Japanese encephalitis, Am. J. Trop. Med. Hyg. 25:733.

Filshie, B. K., and Rehacek, J., 1968, Studies of the morphology of Murray Valley encephalitis and Japanese encephalitis viruses growing in cultured mosquito cells, Virology 34:435.

Fokina, G. I., Malenko, G. V., Levina, L. S., Koreshkova, G. V., Rzhakhova, O. E., Mamonenko, L. L., Pogodina, V. V., and Frolova, M. P., 1982, Persistence of tick-borne encephalitis virus in monkeys. V. Virus localization after subcutaneous inoculations, Acta. Virol. 26:369.

Frolova, M. P., and Pododina, V. V., 1984, Persistence of tick-borne encephalitis virus in monkeys. VI. Pathomorphology of chronic infection in central nervous system, Acta. Virol. 28:232.

Gollins, S. W., and Porterfield, J. S., 1984, Flavivirus infection enhancement in macrophages: Radioactive and biological studies on the effect of antibody on viral fate, J. Gen. Virol. 65:1261.

Gollins, S. W., and Porterfield, J. S., 1985, Flavivirus infection enhancement in macrophages: an electron microscopic study of viral cellular entry, I. Gen. Virol. 66:1969.

Grimley, P. M., 1983, Arbovirus encephalitis: Which road traveled by makes all the difference?, Lab. Invest. 48:369.

Grun, J. B., and Brinton, M. A., 1986a, Characterization of West Nile viral RNA-dependent RNA polymerase and cellular terminal adenylyl and uridylyl transferase in cell-free extracts, J. Virol., submitted.

Grun, J. B., and Brinton, M. A., 1986b, Enhancement of in vitro West Nile virus RNAdependent RNA polymerase activity, J. Virol., submitted.

Halle, S., and Zebovitz, E., 1977, A spontaneous temperature sensitive mutant of Japanese encephalitis virus: Preliminary characterization, Arch Virol. 54:165.

Halstead, S. B., 1980, Immunological parameters of togavirus disease syndromes, in: The Togaviruses (R. W. Schlesinger, ed.), pp. 107-173; Academic Press, New York.

Halstead, S. B., 1981, The pathogenesis of dengue: Molecular epidemiology in infectious disease: The 1981 Alexander D. Langmuir Lecture, Am. J. Epidemiol. 114:632. 
Halstead, S. B., 1982, Immune enhancement of viral infection, in: Progress in Allergy (P. Kallos, ed.), pp. 301-364, S. Karger, Basel.

Halstead, S. B., and O'Rourke, E. J., 1977, Dengue viruses and mononuclear phagocytes. I. Infection enhancement by non-neutralizing antibody, J. Exp. Med. 146:201.

Halstead, S. B., Marchette, N. J., Chow, J. S., and Lolekha, S., 1976, Dengue virus replication enhancement in peripheral blood leukocytes from immune human beings, Proc. Soc. Exp. Biol. Med. 151:136.

Halstead, S. B., Porterfield, J. S., and O'Rourke, E. J., 1980, Enhancement of dengue infection in monocytes by flavivirus antisera, Am. J. Trop. Med. Hyg. 29:638.

Halstead, S. B., Rojanasuphot, S., and Sangkawibha, N., 1983, Original antigenic sin in dengue, Am. J. Trop. Med. Hyg. 32:154.

Halstead, S. B., Venkateshan, C. N., Gentry, M. K., and Larsen, L. K., 1984, Heterogeneity of infection enhancement of dengue 2 strains by monoclonal antibodies, J. Immunol. 132:1529.

Hammon, W. McD., Rohitaydhin, S., and Rhim, J. S., 1963, Studies on Japanese B encephalitis virus vaccines from tissue culture. IV. Preparation and characterization of a pool of attenuated Oct-541 line for human vaccine trial, J. Immunol. 91:295.

Harrison, A. K., Murphy, F. A., and Gardner, J. J., 1982, Visceral target organs in systemic St. Louis encephalitis virus infection of hamsters, Exp. Mol. Pathol. 37:292.

Heinz, F. X., and Kunz, C., 1982, Molecular epidemiology of tick-borne encephalitis virus: Peptide mapping of large non-structural proteins of European isolates and comparison with other flaviviruses, J. Gen. Virol. 62:271.

Heinz, F. X., Berger, R., Tuma, W., and Kunz, C., 1983, A topological and functional model of epitopes on the structural glycoprotein of tick-borne encephalitis virus defined by monoclonal antibodies, Virology 126:525.

Henchal, E. A., Gentry, M. K., McCown, J. M., and Brandt, W. E., 1982, Dengue virus-specific and flavivirus group determinants identified with monoclonal antibodies by indirect immunofluorescence, Am. J. Trop. Med. Hyg. 31:830.

Holland, J. J., Villarreal, L. P., and Breindl, M., 1976, Factors involved in the generation and replication of rhabdovirus defective T particles, J. Virol. 17:805.

Hollingshead, P. G., Jr., Brawner, T. A., and Fleming, T. P., 1983, St. Louis encephalitis virus temperature-sensitive mutants. I. Induction, isolation and preliminary characterization, Arch. Virol. 75:171.

Hotta, S., and Evans, C. A., 1956, Cultivation of mouse-adapted dengue virus (type 1) in rhesus monkey tissue culture, $J$. Infect. Dis. 98:88.

Hotta, H., Hotta, S., Takada, H., Kotani, S., Tanaka, S., and Ohki, M., 1983, Enhancement of dengue virus type 2 replication in mouse macrophage cultures by bacterial cell walls, peptidoglycans, and a polymer of peptidoglycan subunits, Infect. Immun. 41:462.

Hotta, H., Wiharta, A. S., and Hotta, S., 1984, Antibody-mediated enhancement of dengue virus infection in mouse macrophage cell lines, Mkl and Mml, Proc. Soc. Exp. Biol. Med. 175:320.

Igarashi, A., 1978, Isolation of Singh's Aedes albopictus cell clone sensitive to dengue and chikungunya viruses, J. Gen Virol. 40:531.

Igarashi, A., 1979, Characteristics of Aedes albopictus cells persistently infected with dengue viruses, Nature (London) 280:690.

Igarashi, A., Harrap, K. A., Casals, J., and Stoller, V., 1976, Morphological, biochemical and serological studies on a viral agent (CFA) which replicates in and causes fusion of Aedes albopictus (Singh) cells, Virology 74:174.

Ilienko, V. I., Platonov, V. G., Komandenko, V. G., Prozorova, I. N., and Panov, A. T., 1974, Pathogenic study on chronic forms of tick-borne encephalitis, Acta Virol. 18:341.

Jarman, R. V., Morgan, P. N., and Duffy, C. E., 1968, Persistence of West Nile virus in L929 mouse fibroblasts, Proc. Soc. Exp. Biol. Med. 129:633.

Kang, C. Y., and Allen, R., 1978, Host function-dependent induction of defective interfering particles of vesicular stomatitis virus, J. Virol. 25:202. 
Katz, E., and Goldblum, N., 1968, Establishment, steady state, and cure of a chronic infection of LLC cells with West Nile virus, Arch. Gesamte Virusforsch. 25:69.

Kliks, S. C., and Halstead, S. B., 1980, An explanation for enhanced virus production in chick embryo cells, Nature (London) 285:504.

Kos, K. A., Osborne, B. A., and Goldsby, R. A., 1975, Inhibition of Group B arbovirus antigen production and replication in cells enucleated with cytochalasin B, J. Virol. 15:913.

Kos, K. A., Goldsby, R. A., and Top, F. H., Jr. 1976, Differential inhibition of flavivirus and alphavirus replication by cordycepin, Abstr. Annu. Meet. Am. Soc. Microbiol., p. 244.

Kuno, G., 1982, Persistent infection of a nonvector mosquito cell line (TRA-171) with dengue viruses, Intervirology 18:45.

Lazzarini, R. A., Keene, J. D., and Schubert, M., 1981, The origins of defective interfering particles of the negative-strand RNA viruses, Cell 26:145.

Leary, K. R., and Blair, C. D., 1980, Sequential events in the morphogenesis of Japanese encephalitis virus, $I$. Ultrastruct. Res. 72:123.

Leary, K. R., and Blair, C. D., 1983, Japanese encephalitis virus replication: Studies on host cell nuclear involvement, Exp. Mol. Pathol. 38:264.

Lee, C., and Schloemer, R. H., 1981, Identification of the antiviral factor in culture medium of mosquito cells persistently infected with Banzi virus, Virology 110:445.

Liprandi, F., and Walder, R., 1983, Replication of virulent and attenuated strains of yellow fever virus in human monocytes and macrophage-like cells (U-937), Arch. Virol. 76:51.

Lubiniecki, A. S., and Henry, C. J., 1974, Autoradiographic localization of RNA synthesis directed by arboviruses in the cytoplasm of infected BHK-21 cells, Proc. Soc. Exp. Biol. Med. 145:1165.

Luukkonen, A., von Bonsdorff, C.-H., and Renkonen, O., 1977, Characterization of Semliki Forest virus grown in mosquito cells: Comparison with the virus from hamster cells, Virology 78:331.

Maguire, T., and Miles, J. A. R., 1965, The arbovirus carrier state in tissue cultures, Arch. Virusforsch. 15:457.

Malenko, G. V., Fokina, G. I., Levina, L. S., Mamonenko, L. E., Rzhakhova, O. E., Pogodina, V. V., and Frolova, M. P., 1982, Persistence of tick-borne encephalitis virus in monkeys. IV. Virus localization after intracerebral inoculation, Acta Virol. 26:362.

Mathews, J. H., and Vorndam, A. V., 1982, Interferon-mediated persistent infection of Saint Louis encephalitis virus in a reptilian cell line, J. Gen. Virol. 61:177.

Mathur, A., Arora, K. L., and Chaturvedi, U. C., 1982, Transplacental Japanese encephalitis virus (JEV) infection in mice during consecutive pregnancies, I. Gen. Virol. 59:213.

Matsumura, T., Stoller, V., and Schlesinger, R. W., 1971, Studies on the nature of dengue viruses. V. Structure and development of dengue virus in Vero cells, Virology 46:344.

Matsumura, T., Stollar, V., and Schlesinger, R. W., 1972, Effect of ionic strength on the release of dengue virus from Vero cells, J. Gen. Virol. 17:343.

Mayer, V., 1963, Two variants of tick-borne encephalitis showing different plaque morphology, Virology 20:372.

Monath, T. P. C., 1971, Neutralizing antibody responses in the major immunoglobulin classes to yellow fever 17D vaccination of humans, Am. J. Epidemiol. 93:122.

Monath, T. (ed.), 1980, St. Louis Encephalitis, American Public Health Association, Washington, D. C.

Monath, T. P., Cropp, C. B., and Harrison, B. S., 1983, Mode of entry of a neurotropic arbovirus into the central nervous system, Lab. Invest. 48:399.

Monckton, R. P., and Westaway, E. G., 1982, Restricted translation of the genome of the flavivirus Kunjin in vitro, J. Gen. Virol. 63:227.

Murphy, F. A., 1980, Togavirus morphology and morphogenesis, in: The Togaviruses (R. W. Schlesinger, ed.), pp. 241-316, Academic Press, New York.

Murphy, F. A., Harrison, A. K., Gary, G. W., Whitfield, S. G., and Forrester, F. T., 1968, St. Louis encephalitis virus infection of mice: Electron microscopic studies of central nervous system, Lab. Invest. 19:652. 
Mussgay, M., Enzmann, P.-J., Horzinek, M. C., and Weiland, E., 1975, Growth cycle of arboviruses in vertebrate and arthropod cells, Prog. Med. Virol. 19:257.

Naeve, C. W., and Trent, D. W., 1977, Identification of Saint Louis encephalitis virus mRNA, Abstracts of the Annual Meeting of the American Society of Microbiology, p. 287, Washington, D. C.

Naeve, C. W., and Trent, D. W., 1978, Identification of Saint Louis encephalitis virus mRNA, J. Virol. 25:535.

$\mathrm{Ng}$, M. L., and Westaway, E. G., 1980, Establishment of persistent infections by flavivirus in Aedes albopictus cells, in: Invertebrate Systems in Vitro (E. Kurstak, K. Maramorosch, and A. Dubendorfer, eds.), pp. 389-402, Elsevier, Amsterdam.

$\mathrm{Ng}$, M. L., and Westaway, E. G., 1983, Phenotypic changes in the flavivirus Kunjin after a single cycle of growth in an Aedes albopictus cell line, J. Gen. Virol. 64:1715.

Ng, M. L., Pedersen, J. S., Toh, B. H., and Westaway, E. G., 1983, Immunofluorescent sites in Vero cells infected with the flavivirus Kunjin, Arch. Virol. 78:177.

Ogawa, M., Okubo, H., Tsuji, Y., Yasui, N., and Someda, K., 1973, Chronic progressive encephalitis occurring 13 years after Russian spring-summer-encephalitis, I. Neurol. Sci. 19:363.

Pang, T., 1983, Immunoepidemiology helps to unravel the mysteries of dengue haemorrhagic fever, Immunol. Today 4:334.

Paul, S. D., 1966, Some biological properties of two variants of Kyasanur Forest disease virus, Indian J. Med. Res. 54:419.

Peiris, J. S. M., and Porterfield, J. S., 1979, Antibody-mediated enhancement of flavivirus replication in macrophage cell lines, Nature (London) 282:509.

Peiris, J. S. M., and Porterfield, J. S., 1981, Antibody-dependent enhancement of plaque formation on cell lines of macrophage origin: A sensitive assay for antiviral antibody, I. Gen. Virol. 57:119.

Peiris, J. S. M., and Porterfield, J. S., 1982, Antibody-dependent plaque enhancement: Its antigenic specificity in relation to Togaviridae, J. Gen. Virol. 58:291.

Peiris, J. S. M., Gordon, S., Unkeless, J. C., and Porterfield, J. S., 1981a, Monoclonal antiFc receptor IgG blocks antibody enchancement of viral replication in macrophages, Nature (London) 289:189.

Peiris, J. S. M., Gordon, S., Porterfield, J. S., and Unkeless, J. C., 1981b, Antibody mediated enhancement of virus replication in macrophage-like cell lines: Its dependence on the Fc receptor in: Heterogeneity of the Mononuclear Phagocytes: Proceedings of an International Workshop (O. Forster and M. Landy, eds.), pp. 469-476, Academic Press, New York.

Peiris, J. S. M., Porterfield, J. S., and Roehrig, J. T., 1982, Monoclonal antibodies against the flavivirus West Nile, J. Gen. Virol. 58:283.

Pfefferkorn, E. R., and Shapiro, D., 1974, Reproduction of small and intermediate RNA viruses, in: Comprehensive Virology 2 (H. Fraenkel-Conrat and R. R. Wagner, eds.), pp. 171-230, Plenum Press, New York.

Phillpotts, R. J., Stephenson, J. R., and Porterfield, J. S., 1985, Antibody dependent enhancement of tick-borne encephalitis virus infectivity, J. Gen. Virol. 66:1831.

Porterfield, J. S., Casals, J., Chumakov, M. P., Gaidamovich, S. Ya, Hannoun, C., Holmes, I. H., Horzinek, M. C., Mussgay, M., Oker-Blom, N., Russell, P. K., and Trent, D. W., 1978, Togaviruses, Intervirology 9:129.

Price, W. H., 1966, Chronic disease and virus persistence in mice inoculated with Kyasanur Forest disease virus, Virology 29:679.

Price, W. H., Lee, R. W., Gunkel, W. F., and O'Leary, W., 1963, The virulence of West Nile virus and TP21 virus and their application to a group B arbovirus vaccine, Am. J. Trop. Med. Hyg. 10:403.

Qureshi, A. A., and Trent, D. W., 1972, Saint Louis encephalitis viral ribonucleic acid replication complex, I. Virol. 9:565.

Qureshi, A. A., and Trent, D. W., 1973a, Group B arbovirus structural and nonstructural 
antigens. I. Serological identification of Saint Louis encephalitis virus soluble antigen, Infect. Immun. 7:242.

Qureshi, A. A., and Trent, D. W., 1973b, Group B arbovirus structural and nonstructural antigens. II. Purification of Saint Louis encephalitis virus intracellular antigens, Infect. Immun. 8:985.

Qureshi, A. A., and Trent, D. W., 1973c, Group B arbovirus structural and nonstructural antigens. III. Serological specificity of solubilized intracellular viral proteins, Infect. Immun. 8:933.

Rice, C. H., Lenches, E. M., Dalgarno, L., Eddy, S. R., Shin, S. J., Sheets, R. L., Trent, D. W., and Strauss, J. H., 1985, Nucleotide sequence of yellow fever virus: Implications for flavivirus gene expression and evolution, Science 229:726.

Roehrig, J. T., Mathews, J. H., and Trent, D. W., 1983, Identification of epitopes on the E glycoprotein of Saint Louis encephalitis virus using monoclonal antibodies, Virology 128:118.

Russell, P. K., Brandt, W. E., and Dalrymple, J. M., 1980, Chemical and antigenic structure of flaviviruses, in: The Togaviruses (R. W. Schlesinger, ed.), pp. 503-529, Academic Press, New York.

Sabin, A. B., 1952a, Nature of inherited resistance to viruses affecting the nervous system, Proc. Natl. Acad. Sci. U.S.A. 38:540.

Sabin, A. B., 1952b, Genetic, hormonal and age factors in natural resistance to certain viruses, Ann. N. Y. Acad. Sci. 54:936.

Sangkawibha, N., Rojanasuphot, S., Ahandrik, S., Viriyapongse, S., Jatanasen, S., Salitul, V., Phanthumachinda, B., and Halstead, S. B., 1984, Risk factors in dengue shock syndrome: A prospective epidemiologic study in Rayong, Thailand, Am. J. Epidemiol. 120:653.

Sawyer, W. A., and Lloyd, W., 1931, The use of mice in tests of immunity against yellow fever, J. Exp. Med. 54:533.

Schlesinger, J. J., and Brandriss, M. W., 1983, 17D yellow fever virus infection of P388D1 cells mediated by monoclonal antibodies: Properties of the macrophage Fc receptor, $J$. Gen. Virol. 64:1255.

Schlesinger, J. J., Brandriss, M. W., and Monath, T. P., 1983, Monoclonal antibodies distinguish between wild and vaccine strains of yellow fever virus by neutralization, hemagglutination inhibition, and immune precipitation of the virus envelope protein, $\mathrm{Vi}$ rology 125:8.

Schlesinger, J. J., Brandriss, M. W., and Walsh, E. E., 1985, Protection against 17D yellow fever encephalitis in mice by passive transfer of monoclonal antibodies to the nonstructural glycoprotein gp48 and by active immunization with gp48, I. Immunol. 135:2805.

Schlesinger, R. W., 1977, Dengue viruses in: Virology Monographs, No. 16, pp. 1-132, Springer-Verlag, New York.

Schmaljohn, C., and Blair, C. D., 1977, Persistent infection of cultured mammalian cells by Japanese encephalitis virus, I. Virol. 24:580.

Schmaljohn, C. S., and Blair, C. D., 1979, Clonal analysis of mammalian cell cultures persistently infected with Japanese encephalitis virus, J. Virol. 31:816.

Schubert, M., Keene, J. D., and Lazzarini, R. A., 1979, A specific internal RNA polymerase recognition site of VSV RNA is involved in the generation of DI particles, Cell 18:749.

Schulze, I. T., and Schlesinger, R. W., 1963, Plaque assay of dengue and other group B arthropod-borne viruses under methyl cellulose overlay media, Virology 19:40.

Shapiro, D., Brandt, W. E., Cardiff, R. D., and Russell, P. K., 1971, The proteins of Japanese encephalitis virus, Virology 44:108.

Shapiro, D., Brandt, W. E., and Russell, P. K., 1972a, Change involving a viral membrane glycoprotein during morphogenesis of group B arboviruses, Virology 50:906.

Shapiro, D., Kos, K., Brandt, W. E., and Russell, P. K., 1972b, Membrane-bound proteins of Japanese encephalitis virus-infected chick embryo cells, Virology 48:360.

Shapiro, D., Trent, D., Brandt, W. E., and Russell, P. K., 1972c, Comparison of the virion polypeptides of Group B arboviruses, Infect. Immun. 6:206. 
Shapiro, D., Kos, K. A., and Russell, P. K., 1973, Japanese encephalitis virus glycoproteins, Virology 56:88.

Shimazu, Y., Aoki, H., and Hotta, S., 1966, Research on dengue in tissue culture. II. Further observations on virus-tissue culture affinity, Kobe J. Med. Sci. 12:189.

Shope, R. E., 1980, Medical significance of togaviruses, in: The Togaviruses (R. W. Schlesinger, ed.), pp. 47-82, Academic Press, New York.

Sinarachatanant, P., and Olson, L. C., 1973, Replication of dengue virus type 2 in Aedes albopictus cell culture, $J$. Virol. 12:275.

Slavin, H. B., 1943, Persistence of the virus of St. Louis encephalitis in the central nervous system of mice for over five months, J. Bacteriol. 46:113.

Smith, A. L., 1981, Genetic resistance to lethal flavivirus encephalitis: Effects of host age and immune status and route of inoculation on production of interfering Banzi virus in vivo, Am. J. Trop. Med. Hyg. 30:1319.

Smith, G. W., and Wright, P. J., 1985, Synthesis of proteins and glycoproteins in dengue type 2 virus-infected Vero and Aedes albopictus cells, J. Gen. Virol. 66:559.

Sriurairatna, S., Bhamarapravati, N., and Phalavadhtana, O., 1973, Dengue virus infection of mice: Morphology and morphogenesis of dengue type 2 virus in suckling mouse neurons, Infect. Immun. 8:1017.

Stephenson, J. R., Lee, J. M., and Wilton-Smith, P. D., 1984, Antigenic variation among members of the tick-borne encephalitis complex, J. Gen. Virol. 65:81.

Stohlman, S. A., Wisseman, C. L., Jr., Eylar, O. R., and Silverman, D. J., 1975, Dengue virus induced modifications of host cell membranes, I. Virol. 16:1017.

Stollar, V., 1980, Togaviruses in cultured arthropod cells, in: The Togaviruses (R. W. Schlesinger, ed.), pp. 583-621, Academic Press, New York.

Stollar, V., Schlesinger, R. W., and Stevens, T. M., 1967, Studies on the nature of dengue viruses. III. RNA synthesis in cells infected with type 2 dengue virus, Virology 33:650.

Stollar, V., Stollar, B. D., Koo, R., Harrap, K. A., and Schlesinger, R. W., 1976, Sialic acid contents of Sindbis virus from vertebrate and mosquito cells, Virology 69:104.

Strauss, E. G., and Strauss, J. H., 1983, Replication strategies of the single stranded RNA viruses of eukaryotes, Curr. Top. Microbiol. Immunol. 105:1.

Strauss, J. H., and Strauss, E. G., 1977, Togaviruses, in: The Molecular Biology of Animal Viruses (D. P. Nayak, ed.), pp. 111-166, Marcel Dekker, New York.

Svitkin, Y. V., Ugarova, T. Y., Chernovskaya, T. V., Lyapustin, V. N., Lashkevich, V. A., and Agol, V. I., 1981, Translation of tick-borne encephalitis virus (flavivirus) genome in vitro: Synthesis of two structural polypeptides, Virology 110:26.

Takeda, H., Oya, A., Hashimoto, K., Yasuda, T., and Yamada, M.-A., 1978, Association of virus specific replicative ribonucleic acid with nuclear membrane in chick embryo cells infected with Japanese encephalitis virus, I. Gen. Virol. 38:281.

Takegami, T., Miyamoto, H., Nakamura, H., and Yasui, K., 1982, Biological activities of the structural proteins of Japanese encephalitis virus, Acta Virol. 26:312.

Takehara, M., 1971, Comparative studies on nucleic acid synthesis and virus-induced RNA polymerase activity in mammalian cells infected with certain arboviruses, Arch. Gesamte. Virusforsch. 34:266.

Takehara, M., 1972, Inhibition of nuclear protein synthesis in BHK-21 cells infected with arboviruses, Arch. Gesamte Virusforsch. 39:163.

Tarr, G. C., and Lubiniecki, A. S., 1976, Chemically-induced temperature sensitive mutants of dengue virus type 2. I. Isolation and partial characterization, Arch. Virol. 50:223.

Theiler, M., 1951, The virus, in: Yellow Fever (G. K. Strode, ed.), pp. 39-136, McGraw-Hill, New York.

Trent, D. W., 1977, Antigenic characterization of flavivirus structural proteins separated by isoelectric focusing, J. Virol. 22:608.

Trent, D. W., and Naeve, C. W., 1980, Biochemistry and replication, in: St. Louis Encephalitis (T. Monath, ed.), pp. 159-199, American Public Health Association, Washington, D. C. 
Trent, D. W., and Qureshi, A. A., 1971, Structural and nonstructural proteins of Saint Louis encephalitis virus, J. Virol. 7:379.

Trent, D. W., Swenson, C. C., and Qureshi, A. A., 1969, Synthesis of Saint Louis encephalitis virus ribonucleic acid in BHK-21/13 cells, J. Virol. 3:385.

Virus Research Center, Poona, 1963, Survival of KFD virus in mice surviving paralysis, Annual Report, p. 109.

Von Magnus, P., 1954, Incomplete forms of influenza virus, Adv. Virus Res. 2:59.

Webster, L. T., 1933, Inherited and acquired factors in resistance to infection. I. Development of resistant and susceptible lines of mice through selective breeding, J. Exp. Med. 57:793.

Webster, L. T., and Clow, A. D., 1936, The limited neurotropic character of the encephalitis virus (St. Louis type) in susceptible mice, J. Exp. Med. 63:433.

Webster, L. T., and Johnson, M. S., 1941, Comparative virulence of St. Louis encephalitis virus cultured with brain tissue from innately susceptible and innately resistant mice, J. Exp. Med. 74:489.

Wengler, G., and Wengler, G., 1981, Terminal sequences of the genome and replication from RNA of the flavivirus West Nile virus: Absence of poly(A) and possible role in RNA replication, Virology 113:544.

Wengler, G., Wengler, G., and Gross, H. J., 1978, Studies on virus-specified nucleic acids synthesized in vertebrate and mosquito cells infected with flaviviruses, Virology 89:423.

Wengler, G., Beato, M., and Wengler, G., 1979, In vitro translation of 42 S virus-specific RNA from cells infected with the flavivirus, West Nile virus, Virology 96:516.

Westaway, E. G., 1973, Proteins specified by group B togaviruses in mammalian cells during productive infections, Virology 51:454.

Westaway, E. G., 1977, Strategy of the flavivirus genome: Evidence for multiple internal initiation of translation of proteins specified by Kunjin virus in mammalian cells, Virology 80:320.

Westaway, E. G., 1980, Replication of flaviviruses, in: The Togaviruses (R. W. Schlesinger, ed.), pp. 531-581, Academic Press, New York.

Westaway, E. G., and Ng, N. L., 1980, Replication of flaviviruses: Separation of translation sites of Kunjin virus proteins and of cells proteins, Virology 106:107.

Westaway, E. G., and Reedman, B. M., 1969, Proteins of the group B arbovirus Kunin, $I$. Virol 4:688.

Westaway, E. G., and Shew, M., 1977, Proteins and glycoproteins specified by the flavivirus Kunjin, Virology 80:309.

Westaway, E. G., Schlesinger, R. W., Dalrymple, J. M., and Trent, D. W., 1980, Nomenclature of flavivirus specified proteins, Intervirology 14:114.

Westaway, E. G., Speight, G., and Endo, L., 1984, Gene order of translation of the flavivirus Kunjin: Further evidence of internal initiation in vivo, Virus Res. 1:333.

Westaway, E. G., Brinton, M. A., Gaidamovich, S. Ya., Horzinek, M. C., Igarashi, A., Kaariainen, L., Lvov, D. K., Porterfield, J. S., Russell, P. K., and Trent, D. W., 1986, Flaviviridae, Intervirology 24:183.

White, J., Kartenbeck, J., and Helenius, A., 1980, Fusion of Semliki Forest virus with the plasma membrane can be induced by low pH, J. Cell Biol. 87:264.

White, J., Matlin, K., and Helenius, A., 1981, Cell fusion by Semliki Forest, influenza, and vesicular stomatitis viruses, J. Cell Biol. 89:674.

Whitfield, S. G., Murphy, F. A., and Sudia, W. D., 1973, St. Louis encephalitis virus: An ultrastructural study of infection in a mosquito vector, Virology 56:70.

Wright, P. J., 1982, Envelope protein of the flavivirus Kunjin is apparently not glycosylated, I. Gen. Virol. 59:29.

Wright, P. J., and Warr, H. M., 1985, Peptide mapping of envelope-related glycoproteins specified by the flaviviruses Kunjin and West Nile, J. Gen. Virol. 66:597.

Wright, P. J., and Westaway, E. G., 1977, Comparisons of the peptide maps of Kunjin virus proteins smaller than the envelope protein, J. Virol. 24:662.

Wright, P. J., Warr, H. M., and Westaway, E. G., 1983, Comparisons by peptide mapping of 
proteins specified by Kuniin, West Nile and Murray Valley encephalitis viruses, Aust. J. Exp. Biol. Med. Sci. 61:641.

Yazuzumi, G., Tsubo, I., Sugihara, R., and Nakai, Y., 1964, Analysis of the development of Japanese B encephalitis (JBE) virus. I. Electron microscope studies of microglia infected with JBE virus, J. Ultrastruct. Res. 11:213.

Zebovitz, E., Leong, J. K. L., and Doughty, S. C., 1972, Japanese encephalitis virus replication: A procedure for the selective isolation and characterization of viral RNA species, Arch. Gesamte Virusforsch. 38:319.

Zebovitz, E., Leong, J. K. L., and Doughty, S. C., 1974, Involvement of host cell nuclear envelope membranes in the replication of Japanese encephalitis virus, Infect. Immun. 10:214.

Zinder, N. (ed.), 1975, RNA Phages, Cold Spring Harbor Press, Cold Spring Harbor, New York.

Zlotnik, I., Grant, D. P., and Carter, J. B., 1976, Experimental infection of monkeys with viruses of the tick-borne encephalitis complex: Degenerative cerebellar lesions following inapparent forms of the disease or recovery from clinical encephalitis, Br. J. Exp. Pathol. 57:200. 